\title{
Antioxidant Activity and Discrimination of Organic Apples (Malus domestica Borkh.) Cultivated in the Western Region of Romania: A DPPH. Kinetics-PCA Approach
}

\author{
Olimpia Alina Iordănescu ${ }^{1,+}$, Maria Băla ${ }^{1,+}$, Alina Carmen Iuga ${ }^{1,+}$, Dina Gligor (Pane) ${ }^{2}$, Ionuţ Dascălu ${ }^{1,+}$, \\ Gabriel Stelian Bujancă ${ }^{3}$, Ioan David ${ }^{4, *}$, Nicoleta Gabriela Hădărugă ${ }^{2,4, * \mathbb{D}}$ and Daniel Ioan Hădărugă ${ }^{2,5}$
}

Citation: Iordănescu, O.A.; Băla, M.; Iuga, A.C.; Gligor (Pane), D.; Dascălu I.; Bujancă, G.S.; David, I.; Hădărugă, N.G.; Hădărugă, D.I. Antioxidant Activity and Discrimination of Organic Apples (Malus domestica Borkh.) Cultivated in the Western Region of Romania: A DPPH. Kinetics-PCA Approach. Plants 2021, 10, 1957. https://doi.org/10.3390/plants10091957

Academic Editors: Liana C. Salanță and Sonia A. Socaci

Received: 2 September 2021

Accepted: 15 September 2021

Published: 19 September 2021

Publisher's Note: MDPI stays neutral with regard to jurisdictional claims in published maps and institutional affiliations.

Copyright: (C) 2021 by the authors. Licensee MDPI, Basel, Switzerland. This article is an open access article distributed under the terms and conditions of the Creative Commons Attribution (CC BY) license (https:/ / creativecommons.org/licenses/by/ $4.0 /$ )
1 Department of Horticulture, Banat's University of Agricultural Sciences and Veterinary Medicine "King Michael I of Romania" from Timişoara, Calea Aradului 119, 300645 Timişoara, Romania; olimpia.iordanescu@yahoo.com (O.A.I.); mariabalamonicabala@yahoo.com (M.B.); i_ali4ever@yahoo.com (A.C.I.); dascalu_ionut91@yahoo.com (I.D.)

2 Doctoral School "Engineering of Vegetable and Animal Resources", Banat's University of Agricultural Sciences and Veterinary Medicine "King Michael I of Romania" from Timişoara, Calea Aradului 119 300645 Timişoara, Romania; gligor_dina_bihor@yahoo.com (D.G.); daniel.hadaruga@upt.ro (D.I.H.)

3 Department of Food Control, Banat's University of Agricultural Sciences and Veterinary Medicine “King Michael I of Romania" from Timişoara, Calea Aradului 119, 300645 Timişoara, Romania; gabrielbujanca@yahoo.com

4 Department of Food Science, Banat's University of Agricultural Sciences and Veterinary Medicine "King Michael I of Romania" from Timişoara, Calea Aradului 119, 300645 Timişoara, Romania

5 Department of Applied Chemistry, Organic and Natural Compounds Engineering, Polytechnic University of Timişoara, Carol Telbisz 6, 300001 Timişoara, Romania

* Correspondence: neda_university@yahoo.com (I.D.); nico_hadaruga@yahoo.com or nicoletahadaruga@usab-tm.ro (N.G.H.); Tel.: +40-256-277-423 (N.G.H.)

+ These authors contributed equally to this work. They are principal authors.

Abstract: Apple (Malus domestica Borkh.) is one of the most used fruit for beverages in Romania. The goal of the study was to evaluate the antioxidant activity and discrimination of various parts of organic and non-organic apple varieties cultivated in the western region of Romania using the DPPH. kinetics-PCA (principal component analysis) approach. Organic and non-organic apples were subjected to solid-liquid ethanol extraction. Core and shell extracts were mixed with DPPH. and spectrophotometrically monitored at $517 \mathrm{~nm}$. Antioxidant activity and mean DPPH. reaction rate at various time ranges reveal significant differences between organic and non-organic samples, as well as apple parts. Organic core and shell extracts had higher antioxidant activities than the corresponding non-organic samples (74.5-96.9\% and 61.9-97.2\%, respectively, 23.5-94.3\% and 59.5-95.5\%). Significant differences were observed for the DPPH. reaction rate for the first $\frac{1}{2} \mathrm{~min}$, especially in the presence of organic core extracts $(3.7-4.8 \mu \mathrm{M} / \mathrm{s})$. The organic samples were well discriminated by $\mathrm{DPPH}$ - kinetics-PCA, the most important variables being the DPPH. reaction rate for the first time range. This is the first DPPH kinetics-PCA approach applied for discriminating between organic and non-organic fruits and can be useful for evaluating the quality of such type of fruits.

Keywords: apple; Malus domestica Borkh.; antioxidant activity; organic and non-organic orchards; $\mathrm{DPPH} \cdot$ kinetics; mean DPPH. reaction rate; principal component analysis discrimination

\section{Introduction}

Apples (Malus domestica Borkh.) have been known and cultivated since ancient times, both in Asia (Anatolia and Persian Empire) and Europe (Roman Empire) [1]. China is the main producer with more than 42.4 Mt in 2019 and an area harvested of more than 2 million of ha [2]. It is followed by the United States of America, Turkey, Poland and India. On the other hand, New Zealand is on the top of the pile regarding apple yield. Romania has 52740 ha of cultivated area and an apple production in 2019 of $2.316 \times 10^{6}$ tons (the 
fourteenth and thirtieth positions, respectively) [2]. Nowadays, more than ten thousand of apple cultivars exist. Among these cultivars, "Golden Delicious", "Florina", "Generos" and "Starkrimson" are mainly cultivated in Romania [2-4]. "Golden Delicious" is a yellow winter apple originating from the United States of America. It is a hybrid of "Grimes golden" and "Golden reinette" cultivars and provides higher productivity and quality [5-8]. The "Florina" cultivar is a winter apple that comes from France. The color is a mixture of yellow-green, with red stripes. It is a combination of "Jonathan", "Golden Delicious" and "Rome" varieties [9]. "Generos" variety was developed in Romania in 1985 from "Parmain d'or $\times$ M. Kaido", "Jonathan $\times$ V 53-39-2" and "Frumos de Voineşti $\times$ V 60-6-51" varieties [10]. It is a winter apple and is resistant against diseases and pests. "Starkrimson" is an apple variety resulting from the "Stark" and "Delicious" cultivars [11,12]. The "Starkrimson" apples are red-colored and have longer shelf life.

Apples are consumed as fresh fruits, but also as other food and beverage products after processing. The quality and chemical composition of apples are changed during storage (cold storage, controlled atmosphere), and especially after processing in order to obtain apple beverages (juice, cider, vinegar, alcoholic beverages) or other food products (jam, sauce, dry or canned apples) [13-16]. Moreover, by-products from apple processing are also used for obtaining various beverages such as apple tea and filter tea, or biologically active compounds by extraction, designed for functional foods [16-18]. Apple processing includes mechanical, thermal and chemical pre-treatments, osmotic dehydration, drying, irradiation, fermentation, clarification, extraction, concentration, steaming, filtration, etc. $[8,13,15,16]$. The main compounds affected by processing are antioxidants, among other nutrients. Fresh apples have a high content of carbohydrates of about $13.8 \%$, especially sugars such as sucrose, glucose and fructose (a total of 10.4\%) [1]. Other constituents are dietary fibers, lipids, proteins, pectins, minerals $(\mathrm{K}, \mathrm{Ca}, \mathrm{Mg}$, $\mathrm{Fe}$ and $\mathrm{P})$, vitamins and carotenoids (vitamins $C, A, E, \beta$-carotene, lutein and zeaxanthin) [1]. Ascorbic acid, benzoic acids, flavonoids, flavonoid glycosides, dihydrochalcones, anthocyanins, proanthocyanidins and cinnamic acid derivatives are the main classes of antioxidant compounds found in apple fruits. Ascorbic acid content varies in wide ranges, e.g., 0.4-13.2 mg/100 g fresh fruit [12] or $13.1 \mathrm{mg} / 100 \mathrm{~mL}$ apple juice [19]. Gallic, $p$-hydroxybenzoic, protocatechuic and syringic acids were the main compounds from the benzoic acid class found in various apple cultivars [20-23]. Flavan-3-ol derivatives were represented by catechin and epicatechin, which were identified in apple fruits in many studies [20-34]. Other flavonoids were quercetin, myricetin, kaempferol, as well as epicatechin di-, tri-, tetramers and epigallocatechin $[20,21,30]$. Flavonoid glycosides were more important in all parts of apple fruits. Almost all were quercetin-based derivatives [1,20-26,28,29,31-36]. Dihydrochalcone derivatives were identified in apples even as aglycones such as phloretin $[1,20,21,26,34]$ or especially as glycosides $[1,22,24,25,29,30]$. Other important antioxidant compounds found in apples belong to the cinnamic acid derivative class. Both hydroxycinnamic acids and cinnamic acid esters with (-)-quinic acid were identified [1,21-35]. Cyanidin-3-O-glucoside and cyanidin-3-O-galactoside from anthocyanidin class, procyanidin B1, B2, and their diand trimers from procyanidin class were also identified in apples $[1,21-27,29,30,32-34]$. These antioxidant compounds have been identified even as individual compounds or as total polyphenols, flavonoids, along with the overall antioxidant activity of various fresh and unprocessed or processed apple cultivars.

Antioxidant activity of fruits and extracts is determined by various methods that include reactions of antioxidant compounds with specific reagents. In this regard, the DPPH. method (2,2-diphenyl-1-picrylhydrazyl) is widely used. The stable DPPH. radical has the ability to scavenge other radicals resulted by homolytic splitting of phenolic or enolic groups in antioxidant compounds [37,38]. The maximum absorbance of DPPH at $517 \mathrm{~nm}$ is shifted to lower values for the neutral reaction products. The DPPH. method was also used in combination with Electron Paramagnetic Resonance (EPR) spectroscopy for direct detection of free radicals in various vegetables, spices and fruits, including apples [7]. Another method used for evaluation of antioxidant activity of fruits is the TEAC/ABTS. ${ }^{+}$assay 
(Trolox equivalent antioxidant capacity /2,2'-azino-bis(3-ethylbenzthiazoline-6-sulfonic acid, radical cation)) [39,40]. FRAP (ferric reducing ability of plasma) of antioxidant compounds and extracts is determined by monitoring the absorbance at $593 \mathrm{~nm}$ [39]. The Folin-Ciocalteu assay allows measurement of the total reducing capacity, including the reaction with phenols and enols [39]. Alvarez and co-workers studied the overall antioxidant activity of apple juices through DPPH., ABTS. ${ }^{+}$and FRAP. The PCA analysis (principal component analysis) allowed differentiation of apple juices by geographical origin and type of juice [35]. The geographical origin was established for the "Golden Delicious" apple variety through DPPH., ABTS. ${ }^{+}$and FRAP methods by Fernández-Jalao and collaborators [24] or through TEAC and FRAP methods by Łysiak et al. for the "Jonagold" variety [29]. Similar studies were performed to evaluate the overall antioxidant activity of different apple cultivars by DPPH . and AEAC (ascorbate equivalent antioxidant capacity) [11], by FRAP technique for flesh and peel of different apple genotypes [25,28], by Folin-Ciocalteu, FRAP, DPPH. and ABTS. ${ }^{+}$methods for flesh, peel and whole apple fruits of various cultivars [33,36,41,42], as well as through DPPH. and FRAP assays for the unripe "Fuji" apple variety at different growing periods [34]. Multivariate statistical analyses such as PCA and PLS (partial least squares/projection in latent structures) were generally used for classifying/grouping or discriminating of apple varieties, processed apples, or apple juices by means of antioxidant compound composition, total antioxidant activity, or spectroscopic methods (FTIR, MIR and NIR-Fourier transform-, middle- and near infrared spectroscopy, UV-Vis spectrophotometry or ${ }^{1} \mathrm{H}-\mathrm{NMR}-{ }^{1} \mathrm{H}$ nuclear magnetic resonance) [35,43-47].

There are many research articles related to the site selection and characteristics, cultivars, soil and crop management, pesticide and pest management, harvest and post-harvest handling of organic apples, as well as consumer preferences [9,48-51]. However, aroma profile of apples from organic orchards, their authentication and processing levels were studied using PCA and PLS multivariate statistical analysis techniques [52-56]. Unfortunately, only a few studies were performed for discriminating between organic apples by means of their antioxidant properties. This is the case for the influence of freezing of organic and conventional apples on the polyphenol content and antioxidant activity. The discrimination of the samples by PLS-DA (discriminant analysis) was conducted [31]. On the other hand, the PCA discrimination of organic and conventional apples by means of the main nutrients (mineral contents and their ratios) [57] or organic apple juices as affected by processing, using antioxidant characteristics (ascorbic acid, polyphenols, total antioxidant capacity, particular antioxidant contents) and organoleptic properties [58] was also investigated. To our knowledge, no research on the application of DPPH· kinetics for the discrimination of organic/local apple varieties was performed.

The goal of the present study was to discriminate organic and non-organic (conventional) apple varieties cultivated in the western region of Romania using the DPPH. kinetics-PCA approach. This is a fast and simple approach based on the determination of the mean DPPH. reaction rates during specific time ranges and is for the first time applied for apple fruits.

\section{Results and Discussion}

\subsection{Radical Scavenging Activity of Apple Extracts}

The antioxidant activity of apple shell and core extracts of various varieties was evaluated as the ability to capture free radicals (radical scavenging activity, RSA, see Section 3.3). Methods of evaluation were based on the use of the stable free radical, 2,2-diphenyl-1-picrylhydrazyl (DPPH·), for which there is a significant hypsochromic displacement, from $517 \mathrm{~nm}$ for the free radical, to values lower than $450 \mathrm{~nm}$ (generally) for the DPPH-H and reaction products derived from the antioxidant compounds. As apple extracts show complex mixtures of compounds with antioxidant activity (mainly flavonoids and flavonoid glycosides-e.g., quercetin-3-O-rutinoside, phenolic acids-e.g., chlorogenic acid, procyanidins-e.g., (+)-catechin, dihydrochalcones—e.g., phloretin-2'- 
O-glucoside, or anthocyanidins and anthocyanins-e.g., cyanidin-3-O-glucoside), their reaction was monitored by recording the absorbance of DPPH- over time, taking into account that possible interferences of the mentioned antioxidant compounds are negligible because the molar absorbance and the concentration of these compounds in the extracts are much lower compared to those of the free radical. These variations in absorbance have an inverse logarithmic allure, more or less accentuated depending on the part of the fruit from which the extract was obtained (see Supplementary Materials, Figures S1-S4). Three specific time ranges were set according to the drift ratios for these pseudo-linear ranges in the Absorbance versus Time plots. The step-by-step procedure looks for the maximization of the drift "1" / drift "2" and drift "2" / drift "3" ratios. For apple varieties (shell and core samples) the drifts and their ratios vary within very large limits. In order to compare the samples, the same time ranges were selected, according to previous conditions: time range " 1 " of 0-30 s, time range " 2 " of 30-180 s, and time range " 3 " of 180-900 s. Representative actual RSA values were selected at approximately a quarter of the second and third time ranges ( $1 \mathrm{~min}$ and $5 \mathrm{~min}$ ), as well as at the upper limits of these ranges ( $3 \mathrm{~min}$ and $15 \mathrm{~min}$ ).

In general, "Golden Delicious" apple shell caused a more pronounced decrease in $\mathrm{DPPH}$ - absorbance in the first period of monitoring. Antioxidant activities were evaluated by RSA values at various monitoring times (Table 1 and Figure S1). Thus, for "Golden Delicious" shell extracts, the RSA values after $60 \mathrm{~s}$ were between 31.6 and $88.7 \%$, while for the corresponding core extracts, they were generally lower (34.2-76.7\%). The highest antioxidant activities were observed for the samples from organic orchard. For the shell extracts, the $R S A$ values were $96.65( \pm 0.72) \%$ and $95.25( \pm 0.27) \%$, at the end of monitoring (Table 1). The same trend is observed for the intermediate moments of time. In general, the antioxidant activity of "Golden Delicious" variety was 1-5\% higher for the shell extracts, compared to the core ones, except for the samples from the supermarket (" $G d(s h) \_M K^{\prime}$ " and “ $\left.G d(c o) \_M K^{\prime \prime}\right)$, where the differences were larger (Table 1).

Table 1. Radical scavenging activity $(R S A \%)$ at various times of monitoring for the extracts obtained from organic and conventional "Golden Delicious" apple varieties. Values are expressed as means ( \pm standard deviation, SD). In a column, values with different superscript letters are significantly different, according to the Tukey HSD (honest significant difference) test $(p<0.05)$. All $p$-level values are presented in the Supplementary Materials (Tables S2-S5).

\begin{tabular}{|c|c|c|c|c|c|}
\hline Code & $\begin{array}{c}\text { Organic or Non-Organic } \\
\text { Orchard }{ }^{1}\end{array}$ & $\begin{array}{c}R S A(1 \mathrm{~min}) \\
(\%)\end{array}$ & $\begin{array}{l}R S A(3 \mathrm{~min}) \\
(\%)\end{array}$ & $\begin{array}{l}R S A(5 \mathrm{~min}) \\
(\%)\end{array}$ & $\begin{array}{c}R S A(15 \mathrm{~min}) \\
(\%)\end{array}$ \\
\hline$G d(s h) \_S R a$ & $O$ & $78.76( \pm 0.67)^{\mathrm{a}}$ & $92.13( \pm 0.29)^{\mathrm{a}}$ & $93.68( \pm 0.35)^{\mathrm{a}}$ & $95.25( \pm 0.27)^{\mathrm{a}}$ \\
\hline Gd(co)_SRa & $O$ & $63.95( \pm 2.21)^{\mathrm{a}}$ & $80.41( \pm 1.34)^{\mathrm{a}}$ & $87.56( \pm 1.29)^{\mathrm{a}}$ & $93.43( \pm 0.62)^{\mathrm{a}}$ \\
\hline$G d(s h) \_S R b$ & $\mathrm{O}$ & $88.65( \pm 1.45)^{\mathrm{a}}$ & $95.66( \pm 0.80)^{\mathrm{a}}$ & $96.24( \pm 0.76)^{\mathrm{a}}$ & $96.65( \pm 0.72)^{\mathrm{a}}$ \\
\hline$G d(c o) \_S R b$ & $O$ & $76.68( \pm 1.54)^{\mathrm{a}}$ & $91.36( \pm 0.64)^{\mathrm{a}}$ & $94.31( \pm 0.47)^{\mathrm{a}}$ & $95.20( \pm 0.28)^{\mathrm{a}}$ \\
\hline$G d(s h) \_A R$ & $N$ & $69.26( \pm 2.62)^{\mathrm{a}}$ & $87.13( \pm 0.65)^{\mathrm{a}}$ & $89.02( \pm 0.17)^{\mathrm{a}}$ & $91.13( \pm 0.05)^{\mathrm{a}}$ \\
\hline$G d(c o) \_A R$ & $N$ & $58.36( \pm 13.23)^{\mathrm{a}}$ & $79.97( \pm 3.97)^{\mathrm{a}}$ & $84.17( \pm 0.18)^{\mathrm{a}}$ & $86.51( \pm 1.70)^{\mathrm{a}}$ \\
\hline$G d(s h) \_L G$ & $N$ & $82.83( \pm 8.27)^{a}$ & $89.35( \pm 2.14)^{\mathrm{a}}$ & $90.19( \pm 1.75)^{\mathrm{a}}$ & $90.78( \pm 1.01)^{\mathrm{a}}$ \\
\hline$G d(c o) \_L G$ & $N$ & $36.72( \pm 0.54)^{b}$ & $67.55( \pm 0.23)^{b}$ & $79.77( \pm 0.22)^{\mathrm{a}}$ & $86.90( \pm 0.84)^{\mathrm{a}}$ \\
\hline$G d(s h) \_M K$ & $N$ & $31.64( \pm 0.43)^{b}$ & $42.29( \pm 0.99)^{\mathrm{c}}$ & $48.80( \pm 1.27)^{b}$ & $60.37( \pm 1.21)^{b}$ \\
\hline$G d(c o) \_M K$ & $N$ & $34.21( \pm 13.6)^{b}$ & $39.13( \pm 15.72)^{\mathrm{c}}$ & $41.59( \pm 17.03)^{b}$ & $45.52( \pm 18.64)^{b}$ \\
\hline
\end{tabular}

${ }^{1} \mathrm{O}$-organic orchard; $\mathrm{N}$-non-organic orchard; ${ }^{\mathrm{a}, \mathrm{b}, \mathrm{c}}$ Values with different superscript letters in a column are significantly different, according to the Tukey HSD test $(p<0.05)$.

To compare the antioxidant activity of apple extracts of various varieties, similar studies were performed for standards, natural or synthetic antioxidant compounds, such as resveratrol and propyl gallate. The variation of DPPH. absorbance in the presence of these antioxidant compounds of various concentrations was also inversely logarithmic, the most active being resveratrol at a concentration of $1 \mathrm{mM}$. It was observed that both resveratrol and propyl gallate show significant antioxidant activity even after $15 \mathrm{~min}$ of monitoring (Table S1). If the RSA values for "Golden Delicious" apple extracts are compared with those for the standard compounds mentioned above, it can be seen that the apple shell extracts are close in $R S A$ value to the final $R S A$ values for standard antioxidant compound 
resveratrol at a concentration of $1 \mathrm{mM}$, respectively, $0.2 \mathrm{mM}$ propyl gallate (82.5-84.2\%, Table S1).

For the "Florina" apple variety, the RSA variations were quite different for the shell samples, compared to the core ones, especially for those from the organic orchard (sample "Fl(sh)_SRa") and from the non-organic orchard (harvested from the conventional orchard, "Fl(sh)_LG") (Figure S2). The biggest differences between the antioxidant activities for the extracts from the shell, respectively, from the core, were observed especially at the beginning of the monitoring, at 1 and 3 min (Figure S2 and Table 2). For example, samples from Lugoj showed $R S A$ values at 1 min of spectrophotometric monitoring of $89.09( \pm 1.95) \%$ for apple shell extracts and only $45.86( \pm 2.17) \%$ for core extracts, differences that remain important even at 3 min of monitoring: $92.98( \pm 0.40) \%$ and, respectively, $70.2( \pm 1.56) \%$ (Table 2). At the end of the analysis, the $R S A$ values were quite close: $93.47( \pm 0.5) \%$ and $90.85( \pm 4.92) \%$ (higher than for the standard solution of $1 \mathrm{mM}$ resveratrol, Table S1). The same behavior was observed for the organic samples from Şiria (especially samples "Fl(sh)_SRa" and " $\left.F l(c o) \_S R a^{\prime \prime}\right)$, for which the $R S A$ values at $1 \mathrm{~min}$ were $85.33( \pm 0.30) \%$ for the shell and $64.43( \pm 2.52) \%$ for the core, respectively, $93.45( \pm 0.06) \%$ and $93.23( \pm 0.16) \%$ at the end of the analysis (Table 2). Lower values were obtained both for the organic " $F l(s h) \_S R b$ " and " $F l(c o) \_S R b$ " samples from SSiria, and especially for the samples from the supermarket (" $F l(s h) \_M K^{\prime \prime}$ and " $\left.F l(c o) \_M K^{\prime \prime}\right)$, for which the antioxidant activity in the core was very low $(25.64( \pm 3.05) \%$, weaker even than the antioxidant activity of resveratrol at the lowest analyzed concentrations of $0.2 \mathrm{mM}$ and $0.1 \mathrm{mM}$ (for which the $R S A$ values were 51.41-59.55\%, Table S1).

Table 2. Radical scavenging activity $(R S A \%)$ at various times of monitoring for the extracts obtained from organic and conventional "Florina" apple varieties. Values are expressed as means ( \pm standard deviation, SD). In a column, values with different superscript letters are significantly different, according to the Tukey HSD (honest significant difference) test $(p<0.05)$. All $p$-level values are presented in the Supplementary Materials (Tables S6-S9).

\begin{tabular}{|c|c|c|c|c|c|}
\hline Code & $\begin{array}{c}\text { Organic or Non-Organic } \\
\text { Orchard }^{1}\end{array}$ & $\begin{array}{c}R S A(1 \mathrm{~min}) \\
(\%)\end{array}$ & $\begin{array}{c}R S A(3 \mathrm{~min}) \\
(\%)\end{array}$ & $\begin{array}{c}R S A(5 \mathrm{~min}) \\
(\%)\end{array}$ & $\begin{array}{c}R S A(15 \mathrm{~min}) \\
(\%)\end{array}$ \\
\hline$F l(s h) \_S R a$ & $O$ & $85.33( \pm 0.30)^{a}$ & $92.47( \pm 0.02)^{a}$ & $93.28( \pm 0.08)^{\mathrm{a}}$ & $93.45( \pm 0.06)^{a}$ \\
\hline$F l(c o) \_S R a$ & $\mathrm{O}$ & $64.43( \pm 2.52)^{b}$ & $86.49( \pm 0.65)^{a}$ & $91.28( \pm 0.14)^{\mathrm{a}}$ & $93.23( \pm 0.16)^{a}$ \\
\hline$F l(s h) \_S R b$ & $\mathrm{O}$ & $61.25( \pm 0.49)^{b}$ & $62.26( \pm 0.70)^{a, b}$ & $62.29( \pm 0.67)^{b}$ & $62.43( \pm 0.68)^{a}$ \\
\hline $\mathrm{Fl}(\mathrm{Co}) \_S R b$ & O & $63.70( \pm 1.64)^{b}$ & $68.90( \pm 1.70)^{a, b}$ & $71.59( \pm 1.76)^{a, b}$ & $74.98( \pm 0.72)^{a}$ \\
\hline$F l(s h) \_L G$ & $N$ & $89.09( \pm 1.95)^{\mathrm{a}}$ & $92.98( \pm 0.40)^{\mathrm{a}}$ & $93.33( \pm 0.48)^{\mathrm{a}}$ & $93.47( \pm 0.50)^{\mathrm{a}}$ \\
\hline$F l(c o) \_L G$ & $N$ & $45.86( \pm 2.17)^{b}$ & $70.20( \pm 1.56)^{a, b}$ & $81.89( \pm 1.15)^{a}$ & $90.85( \pm 4.92)^{\mathrm{a}}$ \\
\hline$F l(s h) \_M K$ & $N$ & $64.41( \pm 10.66)^{b}$ & $71.16( \pm 13.00)^{a, b}$ & $74.14( \pm 14.02)^{\mathrm{a}}$ & $79.30( \pm 15.62)^{\mathrm{a}}$ \\
\hline$F l(c o) \_M K$ & $N$ & $16.64( \pm 3.04)^{c}$ & $20.21( \pm 3.49)^{\mathrm{c}}$ & $22.41( \pm 3.05)^{\mathrm{c}}$ & $25.64( \pm 3.05)^{b}$ \\
\hline
\end{tabular}

${ }^{1} \mathrm{O}$-organic orchard; $\mathrm{N}$-non-organic orchard; ${ }^{\mathrm{a}, \mathrm{b}, \mathrm{c}}$ Values with different superscript letters in a column are significantly different, according to the Tukey HSD test $(p<0.05)$.

The "Generos" apple variety showed interesting behavior in terms of antioxidant activity compared to the other varieties analyzed. The decrease in absorbance for "Generos" apple core extracts is significant even after $900 \mathrm{~s}$ of monitoring, and in the case of the organic " $G n(c o) \_S R^{\prime}$ samples from Şiria it is even more accentuated for these apple core extracts. Quantification of this behavior by RSA (Figure S3 and Table 3) led to intermediate values at 3 min almost identical for the organic samples from Şiria $(78.45( \pm 0.04) \%$ and $78.13( \pm 3.08) \%$ for the shell and core samples), and at the end of the analysis, $79.12( \pm 0.14) \%$ and $94.69( \pm 0.27) \%$ for the same extracts, values similar to those of $0.2 \mathrm{mM}$ propyl gallate for the first case and higher than that of resveratrol at a concentration of $1 \mathrm{mM}$ (see Table S1). 
Table 3. Radical scavenging activity $(R S A \%)$ at various times of monitoring for the extracts obtained from organic and conventional "Generos" apple varieties. Values are expressed as means ( \pm standard deviation, SD). In a column, values with different superscript letters are significantly different, according to the Tukey HSD (honest significant difference) test $(p<0.05)$. All $p$-level values are presented in the Supplementary Materials (Tables S10-S13).

\begin{tabular}{|c|c|c|c|c|c|}
\hline Code & $\begin{array}{c}\text { Organic or Non-Organic } \\
\text { Orchard }^{1}\end{array}$ & $\begin{array}{l}R S A(1 \mathrm{~min}) \\
(\%)\end{array}$ & $\begin{array}{c}R S A(3 \mathrm{~min}) \\
(\%)\end{array}$ & $\begin{array}{c}R S A(5 \mathrm{~min}) \\
(\%)\end{array}$ & $\begin{array}{c}R S A(15 \mathrm{~min}) \\
(\%)\end{array}$ \\
\hline$G n(s h) \_S R$ & $O$ & $75.32( \pm 1.37)^{\mathrm{a}}$ & $78.45( \pm 0.04)^{\mathrm{a}}$ & $78.69( \pm 0.06)^{\mathrm{a}}$ & $79.12( \pm 0.14)^{2}$ \\
\hline$G n(c o) \_S R$ & $O$ & $64.81( \pm 4.56)^{\mathrm{a}}$ & $78.13( \pm 3.08)^{\mathrm{a}}$ & $84.89( \pm 2.21)^{b}$ & $94.69( \pm 0.27)$ \\
\hline$G n(s h) \_L G$ & $N$ & $75.80( \pm 2.09)^{\mathrm{a}}$ & $89.56( \pm 1.05)^{\mathrm{a}}$ & $93.00( \pm 0.74)^{\mathrm{c}}$ & $95.19( \pm 0.49)$ \\
\hline$G n(c o) \_L G$ & $N$ & $41.28( \pm 2.03)^{b}$ & $55.88( \pm 2.37)^{b}$ & $64.33( \pm 1.89)^{\mathrm{d}}$ & $82.78( \pm 1.53)$ \\
\hline
\end{tabular}

${ }^{1} \mathrm{O}$-organic orchard; $\mathrm{N}$-non-organic orchard; $\mathrm{a}, \mathrm{b}, \mathrm{c}, \mathrm{d}$ Values with different superscript letters in a column are significantly different, according to the Tukey HSD test $(p<0.05)$.

Behaviors similar to those for "Generos" apple shell and core extracts were also observed for the "Starkrimson" apple variety, all from organic orchard (samples "SRa" and "SRb", Figure S4 and Table 4). Thus, if at $1 \mathrm{~min}$ of determination the RSA values for the shell samples from organic orchard (samples "Sk(sh)_SRa" and "Sk(sh)_SRb") were $90.16( \pm 1.25) \%$ and $91.78( \pm 0.1) \%$, respectively, for core samples $71.77( \pm 2.75) \%$, at the end of the monitoring they became very close: $93.00-94.71 \%$ for the shell samples, respectively, $96.63 \%$ for the core ones. These values are higher than the most active standard solutions of $1 \mathrm{mM}$ resveratrol and $0.2 \mathrm{mM}$ propyl gallate (Figure S4, Tables 4 and S1). For the supermarket samples, the antioxidant activities for "Starkrimson" apple shell extracts were double compared to those for core extracts, throughout the spectrophotometric monitoring (48.37 $( \pm 1.57) \%$ and $26.05( \pm 2.27) \%$ at $1 \mathrm{~min}$ of monitoring, respectively, $90.39( \pm 0.65) \%$ and $44.89( \pm 4.16) \%$ at the end of the monitoring, Figure S4 and Table 4$)$.

Table 4. Radical scavenging activity $(R S A \%)$ at various times of monitoring for the extracts obtained from organic and conventional "Starkrimson" apple varieties. Values are expressed as means ( \pm standard deviation, SD). In a column, values with different superscript letters are significantly different, according to the Tukey HSD (honest significant difference) test $(p<0.05)$. All $p$-level values are presented in the Supplementary Materials (Tables S14-S17).

\begin{tabular}{|c|c|c|c|c|c|}
\hline Code & $\begin{array}{c}\text { Organic or Non-Organic } \\
\text { Orchard }^{1}\end{array}$ & $\begin{array}{c}R S A(1 \mathrm{~min}) \\
(\%)\end{array}$ & $\begin{array}{c}R S A(3 \mathrm{~min}) \\
(\%)\end{array}$ & $\begin{array}{c}R S A(5 \mathrm{~min}) \\
(\%)\end{array}$ & $\begin{array}{c}R S A(15 \mathrm{~min}) \\
(\%)\end{array}$ \\
\hline$S k(s h) \_S R a$ & $O$ & $90.16( \pm 1.25)^{\mathrm{a}}$ & $94.04( \pm 0.57)^{\mathrm{a}}$ & $94.52( \pm 0.48)^{\mathrm{a}}$ & $94.71( \pm 0.39)^{\mathrm{a}}$ \\
\hline$S k(c o) \_S R a$ & $\mathrm{O}$ & $71.77( \pm 2.75)^{b}$ & $87.97( \pm 1.73)^{\mathrm{a}}$ & $93.67( \pm 1.03)^{\mathrm{a}}$ & $96.63( \pm 0.42)^{a}$ \\
\hline$S k(s h) \_S R b$ & $O$ & $91.78( \pm 0.10)^{\mathrm{a}}$ & $92.71( \pm 0.44)^{\mathrm{a}}$ & $92.89( \pm 0.95)^{\mathrm{a}}$ & $93.00( \pm 1.37)^{a}$ \\
\hline$S k(s h) \_M K$ & $N$ & $48.37( \pm 1.57)^{\mathrm{c}}$ & $68.23( \pm 1.47)^{b}$ & $77.59( \pm 1.52)^{b}$ & $90.39( \pm 0.65)^{a}$ \\
\hline$S k(c o) \_M K$ & $N$ & $26.05( \pm 2.27)^{\mathrm{d}}$ & $32.71( \pm 2.56)^{\mathrm{c}}$ & $36.77( \pm 3.07)^{\mathrm{c}}$ & $44.89( \pm 4.16)^{b}$ \\
\hline
\end{tabular}

${ }^{1} \mathrm{O}$-organic orchard; $\mathrm{N}$-non-organic orchard; $\mathrm{a}, \mathrm{b}, \mathrm{c}, \mathrm{d}$ Values with different superscript letters in a column are significantly different, according to the Tukey HSD test $(p<0.05)$.

There are some studies regarding the overall antioxidant activity of apples and other fruits, including the DPPH - method. The antioxidant activity (measured by the DPPH. method and expressed as mg TE/L) of apple beverages from various geographical origins was well correlated with other antioxidant-related parameters such as total phenolic/flavonoid contents or the concentration of some specific antioxidant compounds [35]. Similar studies on the overall antioxidant activity allow clustering of apple cultivars by location or processing technology $[20,24,59,60]$. DPPH--based methods were also used for evaluating the freely soluble and deeply bound antioxidants in organic apple juices [58]. These parameters, combined with organoleptic ones, allowed classification of organic apple juices according to pressing technology. Our previous studies revealed important antioxidant activities, according to DPPH. radical scavenging activity [61-64]. Pomegranate extracts were differentiated by DPPH--based antioxidant activity according to the ethanolwater ratio or fruit parts $[65,66]$. On the other hand, various parts of kiwi and papaya fruits were differentiated through their DPPH- antioxidant activity $[67,68]$. Kiwi shell extracts 
had higher antioxidant activity than the core samples. Similarly, ripe papaya extracts were more active from this point of view.

\subsection{DPPH· Kinetics Approach for the Apple Extracts}

The behavior of apple extracts in the presence of free radicals can be easily evaluated to compare the various samples in terms of antioxidant activity, not only as the actual value (RSA values at various times). It can be achieved by studying the reaction kinetics of antioxidant compounds in extracts with free radical DPPH. The variation of the concentration of DPPH. in time, in the presence of these antioxidant compounds, has pseudo-linear ranges, observed mainly on the time intervals 0-30 s (interval "1"), 30-180 s (interval "2") and 180-900 s (interval "3"). These time ranges were selected according to drift ratios of successive ranges in the Absorbance versus Time plots, as was mentioned above (see Section 2.1). They were maximized with the restriction of havingthe same time range limits. Consequently, the following drift ratios were obtained, respectively: drift "1" / drift "2" ratios of 5.8-18.8 and 2.5-16.3 for "Golden Delicious" shell and core samples, drift "2" / drift " 3 " ratios of 3.0-101.4 and 5.9-40.7 for "Golden Delicious" shell and core samples; drift "1" / drift "2" ratios of 18.7-127.9 and 3.9-37.5 for "Florina" shell and core samples, drift "2" / drift "3" ratios of 5.4-138.3 and 4.8-41.2 for "Florina" shell and core samples; drift "1" / drift "2" ratios of 11.6-33.0 and 6.5-9.9 for "Generos" shell and core samples, drift "2" / drift " 3 " ratios of 26.0-52.9 and 6.0-7.5 for "Generos" shell and core samples; drift "1" / drift "2" ratios of 5.4-170.7 and 7.5-9.6 for "Starkrimson" shell and core samples, drift "2" / drift "3" ratios of 6.7-115.3 and 4.7-19.9 for "Starkrimson" shell and core samples.

The ratio of the variation of the DPPH. concentration $\left(\triangle C_{D P P H}, \mu \mathrm{M}\right.$, variation with negative value due to the decrease in the concentration over time) to the considered time interval $(\Delta t, \mathrm{~s})$ represents the mean reaction rate of DPPH $\left(\bar{v}_{1-3}, \mu \mathrm{M} / \mathrm{s}\right.$, see Section 3.4) with antioxidant compounds in extracts. Antioxidant compounds belong to various structural classes and have various behaviors in reaction with free radicals. Thus, these mean DPPH. reaction rates were compared for the time intervals considered, for the extracts from various parts of the fruit, respectively, for standard solutions of natural and synthetic antioxidant compounds (resveratrol and propyl gallate).

The mean DPPH reaction rates in the presence of the "Golden Delicious" apple shell extracts were generally higher for the first time interval, compared to the case of core extracts, the values being between 4.25 and $5.65 \mu \mathrm{M} / \mathrm{s}$ and 2.1 and $4.8 \mu \mathrm{M} / \mathrm{s}$, respectively, for the organic and non-organic samples harvested directly from the orchards (samples " $G d(s h) \_S R a$ " / $G d(c o) \_S R a$ ", "Gd(sh)_SRb" / "Gd(co)_SRa", “Gd(sh)_AR" / $G d(c o) \_A R$ " and " $G d(s h) \_L G$ " / $G d(c o) \_L G$ ", Table 5, Figures 1a,b and S5), while for the samples from the supermarket, the values of these rates were quite close, $1.75( \pm 0.07) \mu \mathrm{M} / \mathrm{s}$ and $2.05( \pm 0.64)$ $\mu \mathrm{M} / \mathrm{s}$ (samples " $G d(s h) \_M K^{\prime}$ " and " $G d(c o) \_M K^{\prime}$ ", Table 5, Figure S5). These values were reversed or at most very close for the second interval, where the DPPH. rates were in the range $0.13-0.85 \mu \mathrm{M} / \mathrm{s}$ (Table 5). With the exception of samples from the supermarket, the mean DPPH. reaction rates over the third time interval were higher for the core samples, compared to those in the shell $(0.017-0.051 \mu \mathrm{M} / \mathrm{s}$ and $0.003-0.013 \mu \mathrm{M} / \mathrm{s}$, respectively), indicating a prolonged antioxidant effect in the first case (even if the absolute $R S A$ value was higher for the shell samples). These values were consistent with those obtained for standard antioxidant solutions, for which the mean DPPH. reaction rates on the first interval were between 2.6 and $4.2 \mu \mathrm{M} / \mathrm{s}$, for the second interval between 0.06 and 0.30 $\mu \mathrm{M} / \mathrm{s}$ and only 0.014 and $0.057 \mu \mathrm{M} / \mathrm{s}$ for the third interval (Table S18). 
Table 5. Values of the mean DPPH reaction rates $\left(\bar{v}_{1}, \bar{v}_{2}\right.$ and $\left.\bar{v}_{3}\right)$ for the extracts obtained from organic and conventional "Golden Delicious" apple varieties (for the three specific time ranges, $\Delta t_{1-3}$ : 0-30 s, 30-180 s and 180-900 s). Values are expressed as means ( \pm standard deviation, SD). In a column, values with different superscript letters are significantly different, according to the Tukey HSD (honest significant difference) test $(p<0.05)$. All $p$-level values are presented in the Supplementary Materials (Tables S19-S21).

\begin{tabular}{|c|c|c|c|c|}
\hline Code & $\begin{array}{c}\text { Organic or Non-Organic } \\
\text { Orchard }^{1}\end{array}$ & $\begin{array}{c}\text { DPPH. Reacti } \\
\text { on Rateon } t_{1} \text { Time Range, } \\
\bar{v}_{1}(\mu \mathrm{M} / \mathrm{s})\end{array}$ & $\begin{array}{c}\text { DPPH. Reaction Rate } \\
\text { on } t_{2} \text { Time Range, } \\
\bar{v}_{2}(\mu \mathrm{M} / \mathrm{s})\end{array}$ & $\begin{array}{c}\text { DPPH. Reaction Rate } \\
\text { on } t_{3} \text { Time Range, } \\
\bar{v}_{3}(\mu \mathrm{M} / \mathrm{s})\end{array}$ \\
\hline$G d(s h) \_S R a$ & $O$ & $4.80( \pm 0.00)^{\mathrm{a}}$ & $0.50( \pm 0.00)^{\mathrm{a}}$ & $0.009( \pm 0.000)^{\mathrm{a}}$ \\
\hline$G d(c o) \_S R a$ & $O$ & $3.90( \pm 0.00)^{\mathrm{a}}$ & $0.50( \pm 0.00)^{\mathrm{a}}$ & $0.039( \pm 0.003)^{b}$ \\
\hline$G d(s h) \_S R b$ & $O$ & $5.65( \pm 0.07)^{\mathrm{a}}$ & $0.30( \pm 0.00)^{a, c}$ & $0.003( \pm 0.000)^{\mathrm{a}}$ \\
\hline$G d(c o) \_S R b$ & $O$ & $4.75( \pm 0.07)^{\mathrm{a}}$ & $0.45( \pm 0.07)^{\mathrm{a}}$ & $0.019( \pm 0.010)^{\mathrm{a}, \mathrm{b}}$ \\
\hline$G d(s h) \_A R$ & $N$ & $4.25( \pm 0.21)^{\mathrm{a}}$ & $0.60( \pm 0.00)^{\mathrm{a}}$ & $0.013( \pm 0.000)^{a, b}$ \\
\hline$G d(c o) \_A R$ & $N$ & $3.70( \pm 0.99)^{a, b}$ & $0.70( \pm 0.14)^{\mathrm{a}}$ & $0.017( \pm 0.013)^{\mathrm{a}, \mathrm{b}}$ \\
\hline$G d(s h) \_L G$ & $N$ & $5.60( \pm 0.85)^{\mathrm{a}}$ & $0.30( \pm 0.28)^{a, c}$ & $0.004( \pm 0.004)^{\mathrm{a}}$ \\
\hline$G d(c o) \_L G$ & $N$ & $2.10( \pm 0.00)^{b}$ & $0.85( \pm 0.07)^{a, b}$ & $0.052( \pm 0.003)^{b}$ \\
\hline$G d(s h) \_M K$ & $N$ & $1.75( \pm 0.07)^{b}$ & $0.30( \pm 0.00)^{a, c}$ & $0.099( \pm 0.002)^{c}$ \\
\hline$G d(c o) \_M K$ & $N$ & $2.05( \pm 0.64)^{b}$ & $0.13( \pm 0.11)^{a, c}$ & $0.022( \pm 0.010)^{a, b}$ \\
\hline
\end{tabular}

${ }^{1} \mathrm{O}$-organic orchard; $\mathrm{N}$-non-organic orchard; ${ }^{\mathrm{a}, \mathrm{b}, \mathrm{c}}$ Values with different superscript letters in a column are significantly different, according to the Tukey HSD test $(p<0.05)$.

For "Florina" shell and core extracts, the mean DPPH. reaction rates showed similar comparative values to those for the first time interval. These were higher or equal for the extracts from the two parts of the apple, being between 3.75 and $6.10 \mu \mathrm{M} / \mathrm{s}$ for the extracts from the shell and 0.95 and $3.75 \mu \mathrm{M} / \mathrm{s}$ for those from the core (Figures 1c,d and S6, Table 6). For the second and third time intervals, the mean $\mathrm{DPPH}$. reaction rates were generally higher for the core extracts, compared to those in the shell $(0.03-0.30 \mu \mathrm{M} / \mathrm{s}$ for the shell and $0.09-0.70 \mu \mathrm{M} / \mathrm{s}$ for core, in the case of the second interval, respectively, 0.001-0.028 $\mu \mathrm{M} / \mathrm{s}$ and $0.016-0.136 \mu \mathrm{M} / \mathrm{s}$, Table 6), highlighting the antioxidant activity even after these monitoring periods.

Table 6. Values of the mean DPPH reaction rates $\left(\bar{v}_{1}, \bar{v}_{2}\right.$ and $\left.\bar{v}_{3}\right)$ for the extracts obtained from organic and conventional "Florina" apple varieties (for the three specific time ranges, $\Delta t_{1-3}: 0-30 \mathrm{~s}, 30-180 \mathrm{~s}$ and 180-900 s). Values are expressed as means ( \pm standard deviation, SD). In a column, values with different superscript letters are significantly different, according to the Tukey HSD (honest significant difference) test $(p<0.05)$. All $p$-level values are presented in the Supplementary Materials (Tables S22-S24).

\begin{tabular}{|c|c|c|c|c|}
\hline Code & $\begin{array}{c}\text { Organic or Non-Organic } \\
\text { Orchard }^{1}\end{array}$ & $\begin{array}{c}\text { DPPH. Reacti } \\
\text { on Rateon } t_{1} \text { Time Range, } \\
\bar{v}_{1}(\mu \mathrm{M} / \mathrm{s})\end{array}$ & $\begin{array}{c}\text { DPPH. Reaction Rate } \\
\text { on } t_{2} \text { Time Range, } \\
\bar{v}_{2}(\mu \mathrm{M} / \mathrm{s})\end{array}$ & $\begin{array}{c}\text { DPPH. Reaction Rate } \\
\text { on } t_{3} \text { Time Range, } \\
\bar{v}_{3}(\mu \mathrm{M} / \mathrm{s})\end{array}$ \\
\hline$F l(s h) \_S R a$ & $O$ & $5.60( \pm 0.00)^{\mathrm{a}}$ & $0.30( \pm 0.00)^{\mathrm{a}}$ & $0.002( \pm 0.000)^{\mathrm{a}}$ \\
\hline$F l(c o) \_S R a$ & $O$ & $3.85( \pm 0.07)^{b}$ & $0.65( \pm 0.07)^{b}$ & $0.016( \pm 0.003)^{\mathrm{a}}$ \\
\hline$F l(s h) \_S R b$ & $\mathrm{O}$ & $3.75( \pm 0.07)^{b}$ & $0.03( \pm 0.01)^{a, c}$ & $0.001^{\mathrm{a}}$ \\
\hline$F l(c o) \_S R b$ & $O$ & $3.75( \pm 0.07)^{\mathrm{b}}$ & $0.10( \pm 0.00)^{a, c}$ & $0.021( \pm 0.005)^{\mathrm{a}}$ \\
\hline$F l(s h) \_L G$ & $N$ & $6.10( \pm 0.42)^{\mathrm{a}}$ & $0.20( \pm 0.14)^{a, c}$ & $0.002( \pm 0.001)^{\mathrm{a}}$ \\
\hline$F l(c o) \_L G$ & $N$ & $2.75( \pm 0.07)^{b, c}$ & $0.70( \pm 0.00)^{b}$ & $0.136( \pm 0.090)^{\mathrm{a}}$ \\
\hline$F l(s h) \_M K$ & $N$ & $3.85( \pm 0.64)^{b}$ & $0.15( \pm 0.07)^{a, c}$ & $0.028( \pm 0.009)^{\mathrm{a}}$ \\
\hline$F l(c o) \_M K$ & $N$ & $0.95( \pm 0.21)^{\mathrm{d}}$ & $0.09( \pm 0.01)^{a, c}$ & $0.018( \pm 0.001)^{\mathrm{a}}$ \\
\hline
\end{tabular}

${ }^{1} \mathrm{O}$-organic orchard; $\mathrm{N}$-non-organic orchard; ${ }^{\mathrm{a}, \mathrm{b}, \mathrm{c}, \mathrm{d}}$ Values with different superscript letters in a column are significantly different, according to the Tukey HSD test $(p<0.05)$. 


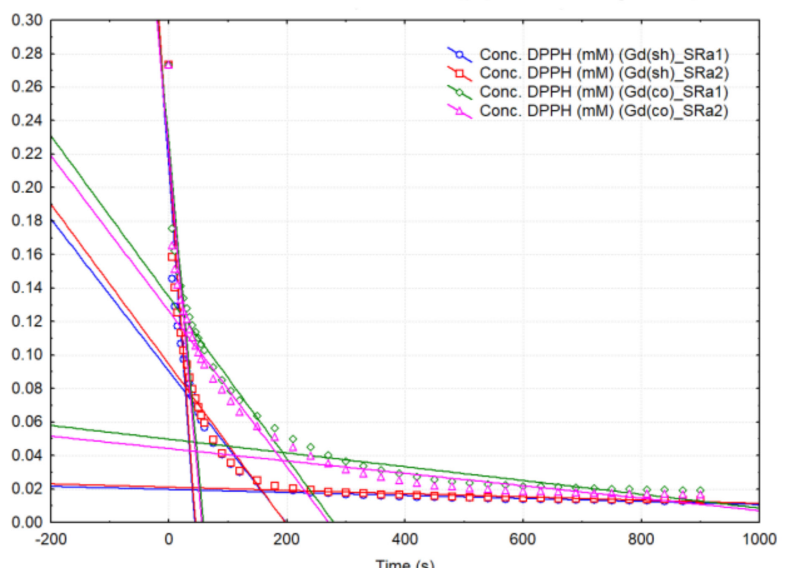

(a)

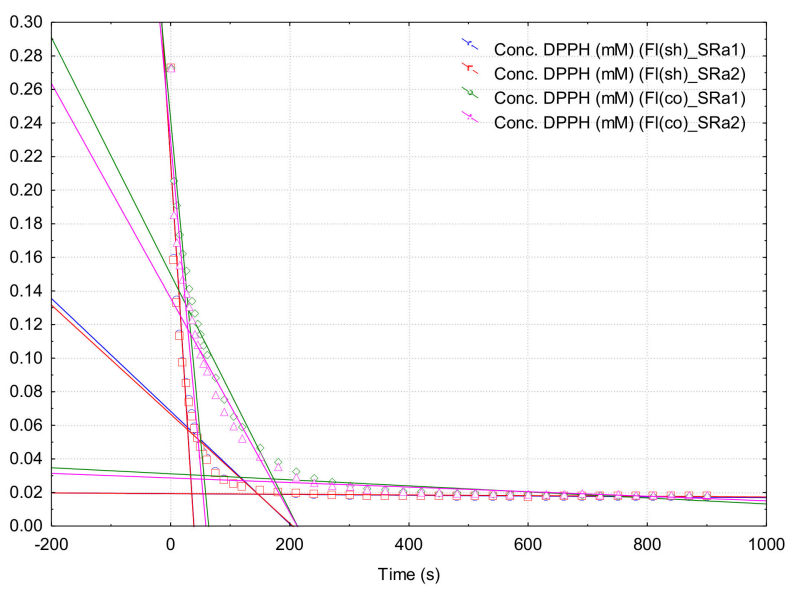

(c)

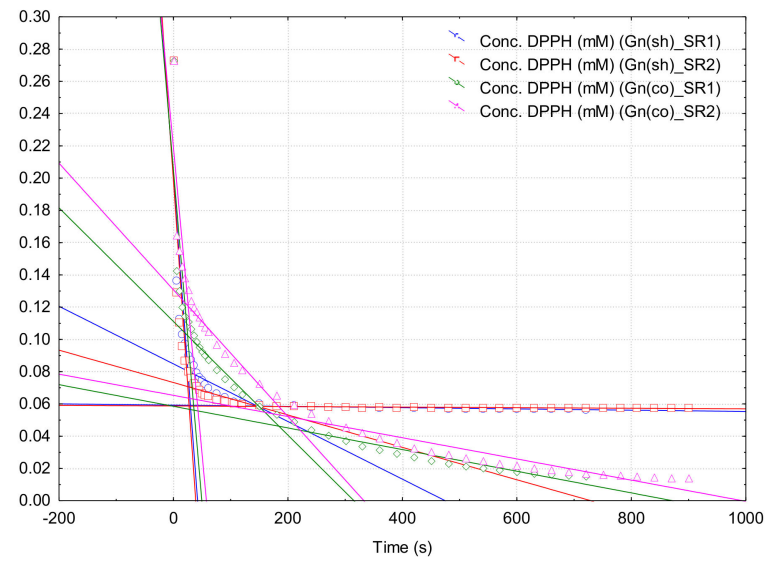

(e)

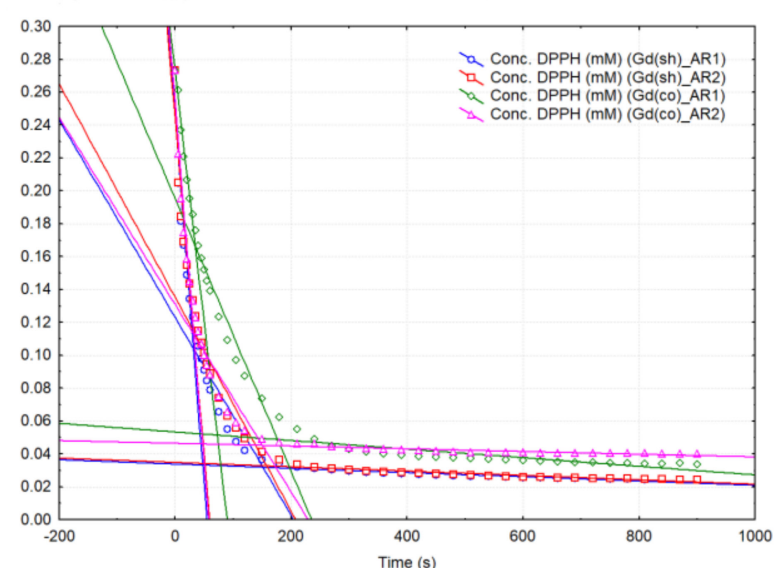

(b)

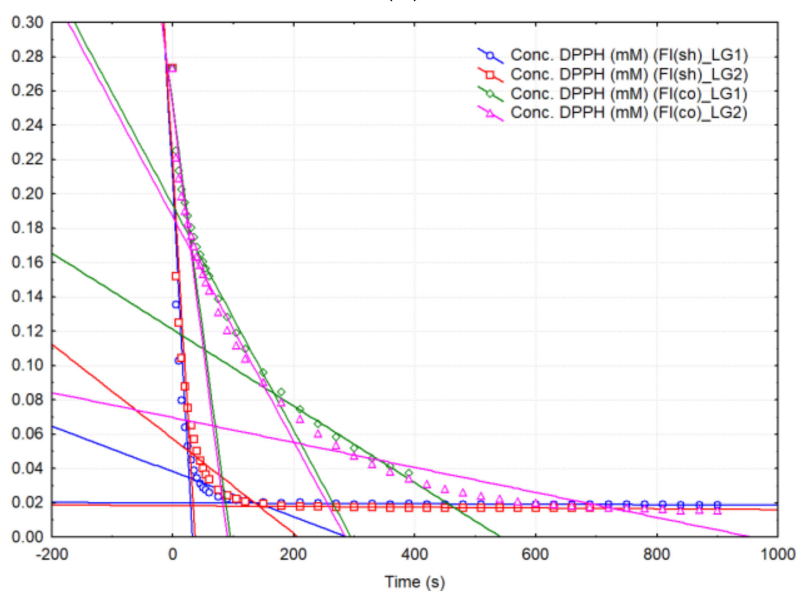

(d)

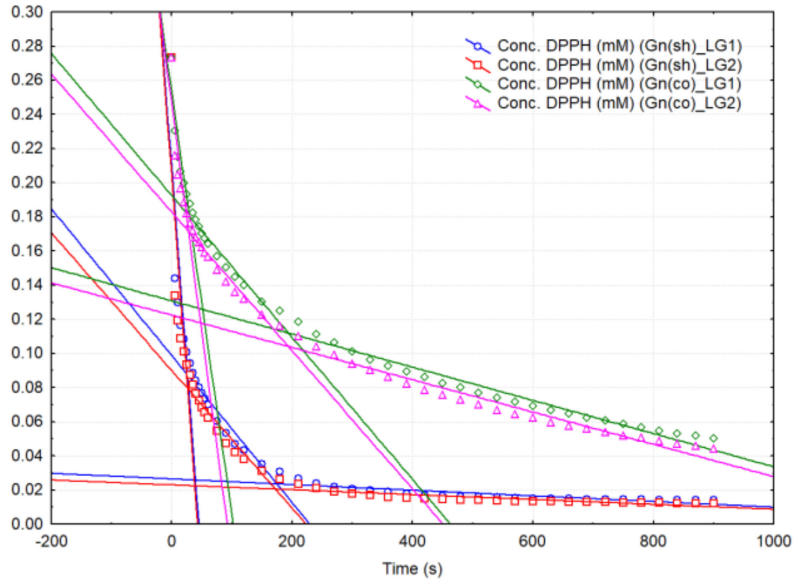

(f)

Figure 1. Cont. 


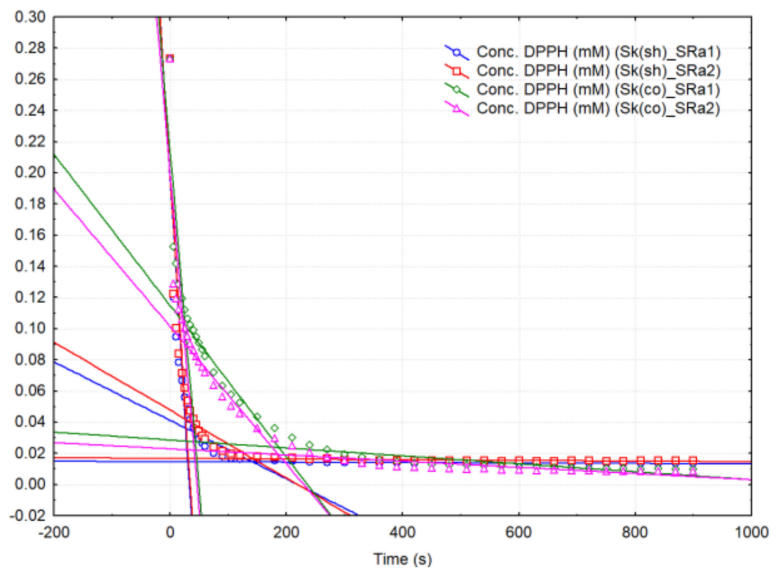

(g)

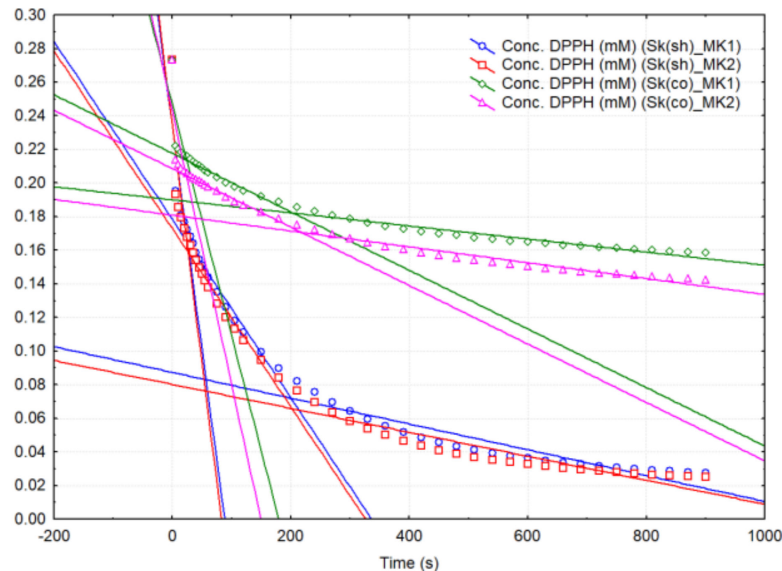

(h)

Figure 1. Variation of the DPPH. concentration during the reaction with antioxidant compounds from the extracts obtained from: (a) the organic shell and core of the "Golden Delicious" apple variety (Gd(sh)_SRa and Gd(co)_SRa); (b) the nonorganic shell and core of the "Golden Delicious" apple variety $\left(G d(s h) \_A R\right.$ and $\left.G d(c o) \_A R\right)$; (c) the organic shell and core of the "Florina" apple variety $\left(F l(s h) \_S R a\right.$ and $\left.F l(c o) \_S R a\right) ;(\mathbf{d})$ the non-organic shell and core of the "Florina" apple variety $\left(F l(s h) \_L G\right.$ and $\left.F l(c o) \_L G\right) ;($ e) the organic shell and core of the "Generos" apple variety (Gn(sh)_SR and Gn(co)_SR); (f) the organic shell and core of the "Generos" apple variety $\left(G n(s h) \_L G\right.$ and $\left.G n(c o) \_L G\right)$; (g) the organic shell and core of the "Starkrimson" apple variety $\left(S k(s h) \_S R a\right.$ and $\left.S k(c o) \_S R a\right)$; (h) the non-organic shell and core of the "Starkrimson" apple variety $\left(S k(s h) \_M K\right.$ and $\left.S k(c o) \_M K\right)$ (all determinations are presented as duplicates "1" and "2"). See Supplementary Materials for all DPPH. kinetic results.

For the "Generos" variety, the largest differences resulting from the kinetic analysis were observed, especially in the case of the mean DPPH. reaction rates for the third time interval (Table 7). The values of these rates for the "Generos" apple samples from the non-organic orchard from Lugoj were only $0.015( \pm 0.002) \mu \mathrm{M} / \mathrm{s}$ for the shell extracts and more than three times higher for the core ones $(0.053( \pm 0.062) \mu \mathrm{M} / \mathrm{s}$, Table 7$)$, while for the organic samples from Şiria (samples " $G n(s h) \_S R$ " and " $G n(c o) \_S R$ ”) these differences were even greater: $0.003( \pm 0.002) \mu \mathrm{M} / \mathrm{s}$ for the shell extracts and $0.066( \pm 0.001) \mu \mathrm{M} / \mathrm{s}$ for those of the "Generos" apple core (Table 7).

Table 7. Values of the mean DPPH reaction rates $\left(\bar{v}_{1}, \bar{v}_{2}\right.$ and $\left.\bar{v}_{3}\right)$ for the extracts obtained from organic and conventional "Generos" apple varieties (for the three specific time ranges, $\Delta t_{1-3}$ : 0-30 s, 30-180 s and 180-900 s). Values are expressed as means ( \pm standard deviation, SD). In a column, values with different superscript letters are significantly different, according to the Tukey HSD (honest significant difference) test $(p<0.05)$. All $p$-level values are presented in the Supplementary Materials (Tables S25-S27).

\begin{tabular}{|c|c|c|c|c|}
\hline Code & $\begin{array}{c}\text { Organic or Non-Organic } \\
\text { Orchard }^{1}\end{array}$ & $\begin{array}{c}\text { DPPH. Reacti } \\
\text { on Rateon } t_{1} \text { Time Range, } \\
\bar{v}_{1}(\mu \mathrm{M} / \mathrm{s})\end{array}$ & $\begin{array}{c}\text { DPPH } \cdot \text { Reaction Rate } \\
\text { on } t_{2} \text { Time Range, } \\
\bar{v}_{2}(\mu \mathrm{M} / \mathrm{s})\end{array}$ & $\begin{array}{c}\text { DPPH. Reaction Rate } \\
\text { on } t_{3} \text { Time Range, } \\
\bar{v}_{3}(\mu \mathrm{M} / \mathrm{s})\end{array}$ \\
\hline$G n(s h) \_S R$ & $\mathrm{O}$ & $4.95( \pm 0.21)^{\mathrm{a}}$ & $0.15( \pm 0.07)^{\mathrm{a}}$ & $0.003( \pm 0.002)^{\mathrm{a}}$ \\
\hline$G n(c o) \_S R$ & $\mathrm{O}$ & $3.95( \pm 0.21)^{b}$ & $0.40( \pm 0.00)^{b}$ & $0.066( \pm 0.001)^{\mathrm{a}}$ \\
\hline$G n(s h) \_L G$ & $N$ & $4.65( \pm 0.07)^{\mathrm{a}}$ & $0.40( \pm 0.00)^{b}$ & $0.015( \pm 0.002)^{\mathrm{a}}$ \\
\hline$G n(c o) \_L G$ & $N$ & $2.60( \pm 0.14)^{c}$ & $0.40( \pm 0.00)^{b}$ & $0.053( \pm 0.062)^{a}$ \\
\hline
\end{tabular}

${ }^{1} \mathrm{O}$-organic orchard; $\mathrm{N}$-non-organic orchard; ${ }^{\mathrm{a}, \mathrm{b}, \mathrm{c}}$ Values with different superscript letters in a column are significantly different, according to the Tukey HSD test $(p<0.05)$.

When comparing the DPPH. kinetics of the "Starkrimson" apple extracts for the organic samples from Şiria, respectively, from the supermarket, a similar behavior was found to the organic ones. Thus, the organic samples from Şiria showed significant rates on the first time interval for "Starkrimson" apple shell extracts $(5.9 \mu \mathrm{M} / \mathrm{s}$, Figure $1 \mathrm{~g}$, Figure S6 and Table 8), and for the core extracts of $4.3 \mu \mathrm{M} / \mathrm{s}$ (Figure $1 \mathrm{~g}$ and Table 8 ). On the other hand, these values were lower for the samples in the supermarket $(2.7( \pm 0.14) \mu \mathrm{M} / \mathrm{s}$ and 1.5 
$( \pm 0.14) \mu \mathrm{M} / \mathrm{s}$, respectively, Figure 1h, Figure S6 and Table 8). For the third interval, only in the case of organic "Starkrimson" apple extracts were higher values found for the reaction rates corresponding to the core extracts, compared to those of the shell $(0.001-0.002 \mu \mathrm{M} / \mathrm{s}$ for shell extracts and $0.023( \pm 0.004) \mu \mathrm{M} / \mathrm{s}$ for core extracts from "Starkrimson" apples from Şiria, Table 8). Antioxidant activity becomes more important in this latest time range for both types of "Starkrimson" apple extracts in the supermarket (0.043-0.074 M/s, Table 8).

Table 8. Values of the mean DPPH reaction rates $\left(\bar{v}_{1}, \bar{v}_{2}\right.$ and $\left.\bar{v}_{3}\right)$ for the extracts obtained from organic and conventional "Starkrimson" apple varieties (for the three specific time ranges, $\Delta t_{1-3}$ : 0-30 s, 30-180 s and 180-900 s). Values are expressed as means ( \pm standard deviation, SD). In a column, values with different superscript letters are significantly different, according to the Tukey HSD (honest significant difference) test $(p<0.05)$. All $p$-level values are presented in the Supplementary Materials (Tables S28-S30).

\begin{tabular}{|c|c|c|c|c|}
\hline Code & $\begin{array}{c}\text { Organic or Non-Organic } \\
\text { Orchard }^{1}\end{array}$ & $\begin{array}{c}\text { DPPH. Reacti } \\
\text { on Rateon } t_{1} \text { Time Range, } \\
\bar{v}_{1}(\mu \mathrm{M} / \mathrm{s})\end{array}$ & $\begin{array}{c}\text { DPPH. Reaction Rate } \\
\text { on } t_{2} \text { Time Range, } \\
\bar{v}_{2}(\mu \mathrm{M} / \mathrm{s})\end{array}$ & $\begin{array}{c}\text { DPPH. Reaction Rate } \\
\text { on } t_{3} \text { Time Range, } \\
\bar{v}_{3}(\mu \mathrm{M} / \mathrm{s})\end{array}$ \\
\hline$S k(s h) \_S R a$ & $O$ & $5.90( \pm 0.14)^{\mathrm{a}}$ & $0.20( \pm 0.00)^{\mathrm{a}}$ & $0.002( \pm 0.001)^{\mathrm{a}}$ \\
\hline$S k(c o) \_S R a$ & $O$ & $4.30( \pm 0.00)^{b}$ & $0.45( \pm 0.07)^{b}$ & $0.023( \pm 0.004)^{b}$ \\
\hline$S k(s h) \_S R b^{*}$ & $\mathrm{O}$ & $5.90( \pm 0.42)^{a}$ & $0.04^{c}$ & $0.001^{\mathrm{a}}$ \\
\hline$S k(s h) \_M K$ & $N$ & $2.70( \pm 0.14)^{c}$ & $0.50( \pm 0.00)^{b}$ & $0.074( \pm 0.004)^{c}$ \\
\hline$S k(c o) \_M K$ & $N$ & $1.50( \pm 0.14)^{d}$ & $0.20( \pm 0.00)^{\mathrm{a}}$ & $0.043( \pm 0.006)^{d}$ \\
\hline
\end{tabular}

${ }^{1} \mathrm{O}$-organic orchard; $\mathrm{N}$-non-organic orchard. * One determination for the latest two time ranges; ${ }^{\mathrm{a}, \mathrm{b}, \mathrm{c}, \mathrm{d}}$ Values with different superscript letters in a column are significantly different, according to the Tukey HSD test $(p<0.05)$.

The previous DPPH · kinetic approach was only applied for specific antioxidant compounds such as synthetic tertbutylhydroxytoluene [69], ascorbic acid, tocopherols, caffeic, ferulic, chlorogenic, sinapic, vanillic, genistic and gallic acids, gallate esters, quercetin, epicatechin, sesamol and curcumin [37,63,70-73] or lemon and pomegranate juices, green tea infusion, purple corn and red-fleshed sweet potato, tomato, pomegranate and kiwi extracts, rosemary essential oil $[66,68,74-76]$. Up to now, no literature data exist on the DPPH. kinetic and PCA classification on organic apple samples. Only a DPPH.-based kinetic model of apple juice enzymatic browning in the presence of cyclodextrins has been investigated [77]. In the present study, a qualitatively correlation between the DPPH. kinetic results and biologically active compound classes contained in various parts of apple samples or as a function of the orchard locations can be performed. In all cases the apple shell samples reveal higher DPPH. reaction rates on the first time range. This means that apple shall samples have a higher content of antioxidant compounds with higher reactivity such as ascorbic acid or flavonoids, dihydrochalcones and cinnamic acid derivatives with less hindered phenolic hydroxyl groups. This observation can also be made for apples obtained from organic orchards, even the locations with approximately the same altitudes (109 $\mathrm{m}$ for the organic orchard and 117-124 $\mathrm{m}$ for non-organic orchards).

\subsection{Correlations and Principal Component Analysis (PCA) of the Antioxidant Activity and DPPH. Kinetics of Apple Extracts}

The overall antioxidant activity, quantified by $R S A$ values at various times or the $\mathrm{DPPH} \cdot$ kinetics parameters, were subjected to linear regression analysis and multivariate statistical analysis. Both statistic procedures allow identification of the significant parameters for differentiation between samples. Thus, linear correlations between the $R S A$ values and mean DPPH. reaction rates provide very good results, especially for the mean DPPH. reaction rate for the first time range, $\bar{v}_{1}$. The correlation with the RSA at $1 \mathrm{~min}$ had the best statistic parameters. The correlation coefficient of $r^{2}=0.982$ was the same even for all datasets ( $n=54$ organic and non-organic apple samples) or for organic apple samples $(n=26)$ (see Equations (1) and (2), as well as graph plots and linear equations in Figures S7 and S9). Correlations with the RSA at other times were also statistically significant, even the correlation coefficients were slightly lower $\left(r^{2}\right.$ of 0.901 for $R S A$ at $3 \mathrm{~min}, 0.825$ for $R S A$ at $5 \mathrm{~min}$ and 0.718 for $R S A$ at $15 \mathrm{~min}, n=54$, Figure S7). On the other hand, mean DPPH. reaction rates on the second and third time ranges do not correlate 
with $R S A$, neither for all dataset, nor for the dataset corresponding to the organic apples (Figures S8 and S9).

$$
\begin{gathered}
\bar{v}_{1}=-0.38( \pm 0.08)+0.068( \pm 0.001) \cdot R S A\left(1^{\prime}\right) \\
n=54, r^{2}=0.982, F=2855, s=0.20, p<0.00001 . \\
\bar{v}_{1}=-0.90( \pm 0.22)+0.0074( \pm 0.003) \cdot R S A\left(1^{\prime}\right)
\end{gathered}
$$

$n=26, r^{2}=0.982, F=632, s=0.16, p<0.00001$.

The classical analyses of these apple varieties ( $n=26$ core samples and $n=12$ organic core samples) were performed in an earlier study and consist of Moisture (g/100 g fresh weight), Minerals (g/100 g fresh weight), $\mathrm{pH}$, Sugar content $\left({ }^{\circ}\right.$ Brix), Total polyphenols (ppm), as well as specific element contents (such as $\mathrm{Cu}, \mathrm{Cr}, \mathrm{Zn}, \mathrm{Fe}, \mathrm{Mn}, \mathrm{K}$, or P, in ppm). The attempt to correlate antioxidant and kinetic parameters with the above-mentioned ones provides interesting results for the $R S A\left(3^{\prime}-15^{\prime}\right)$ versus $p H$ (the correlation coefficient, $r$, was 0.41 for the $R S A\left(15^{\prime}\right)$ parameter; for all apple core samples, $\left.n=26\right)$. On the other hand, the mean DPPH. reaction rate on the second time range, $\bar{v}_{2}$, correlates well with the $p H$ parameter $(r=0.52, n=26)$. Valuable correlations were obtained if the organic samples were considered. Thus, Sugar content $\left({ }^{\circ}\right.$ Brix) correlates well with almost all RSA and DPPH. kinetic parameters $\left(R S A\left(1^{\prime}-15^{\prime}\right)\right.$ versus Sugar content, $r=0.64-0.88, n=12$; $\bar{v}_{1}$ versus Sugar content, $r=0.92, n=12$ ). These observations suggest that the high content of antioxidants with glycoside groups (one of the most important antioxidant class in apples-e.g., flavonoid glycosides, dihydrochalcone glycosides as well as anthocyanins) that can hydrolyze to free sugars agreed with the high RSA values. Moreover, high acidic condition (lower $p H$ ) reduces the overall antioxidant activity (see Supplementary Materials for linear correlations between RSA or DPPH. kinetic parameters and $p H$ or Sugar content, Equations (S1)-(S9)).

Due to partial intercorrelations between $R S A$ and mean DPPH. reaction rates (i.e., $\bar{v}_{1}$ ), the multivariate statistical analysis techniques can process the big dataset by removing the inconvenience of overlapping. Principal component analysis (PCA) uses the maximum variance of the data in order to transform the original axes (parameters) into new axes named principal components $(P C s)$ or factors. The $P C s$ are orthogonal and the intercorrelations are removed. The graph representation of the translation coordinates provides the scores plot and reveals the similarity/dissimilarity between cases (the grouping of the samples). On the other hand, the graph representation of the cosines of the rotational angles provides the loadings plot, which reveals the importance of the original parameters to the classification.

In the case of organic and non-organic apples, shell and core extracts were considered as cases, while the original parameters were RSA and mean DPPH reaction rates at considered times. The attempt to use apple variety as discrimination parameter does not provide clear classifications of the samples, as is presented in Figure $\mathrm{S} 10$ for $P C_{2}$ versus $P C_{1}$ scores plot. However, almost all "Golden Delicious" and "Starkrimson" varieties are grouped in the central-left region of the $P C_{2}$ versus $P C_{1}$ scores plot (similar grouping can be observed in the $P C_{3}$ versus $P C_{1}$ scores plot in Figure S11). All RSA parameters are significant for the $P C_{1}$, as well as the mean DPPH reaction rate on the first time range, $\bar{v}_{1}$. On the other hand, the mean DPPH. reaction rates $\bar{v}_{2}$ and $\bar{v}_{2}$ are significant for the $P C_{2}$ in the PCA analysis. The first two PCs explain $92.16 \%$ of the variance of the antioxidant activity and DPPH. kinetics data $\left(67.60 \%\right.$ for $P C_{1}$ and $24.56 \%$ for $P C_{2}$, Figure $\left.\mathrm{S} 11\right)$.

The PCA approach was then focused to the discrimination between apple parts (coded as " $S$ " for shell and " $C$ " for core of the apple in PCA). The shell cases were more grouped in the center of the $P C_{2}$ versus $P C_{1}$ and $P C_{3}$ versus $P C_{1}$ scores plots, while core samples had a larger distribution (Figure S12). Good results were obtained if the organic ("O") and non-organic ("N") samples were considered in PCA. In both $P C_{2}$ versus $P C_{1}$ and $P C_{3}$ versus $P C_{1}$ scores plots, organic apple samples are well grouped in the center of these plots. 
They are more similar than non-organic samples, which have a wide distribution (Figure 2). The influence of $R S A$ and $\bar{v}_{1}$ for $P C_{1}$, as well as $\bar{v}_{2}$ and $\bar{v}_{3}$ for $P C_{2}$ are the same such as for the above-mentioned classifications.

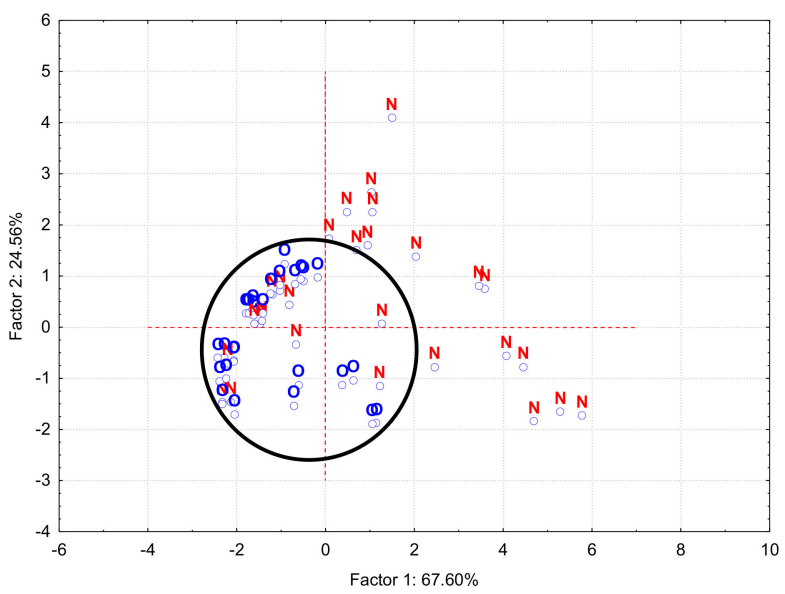

(a)

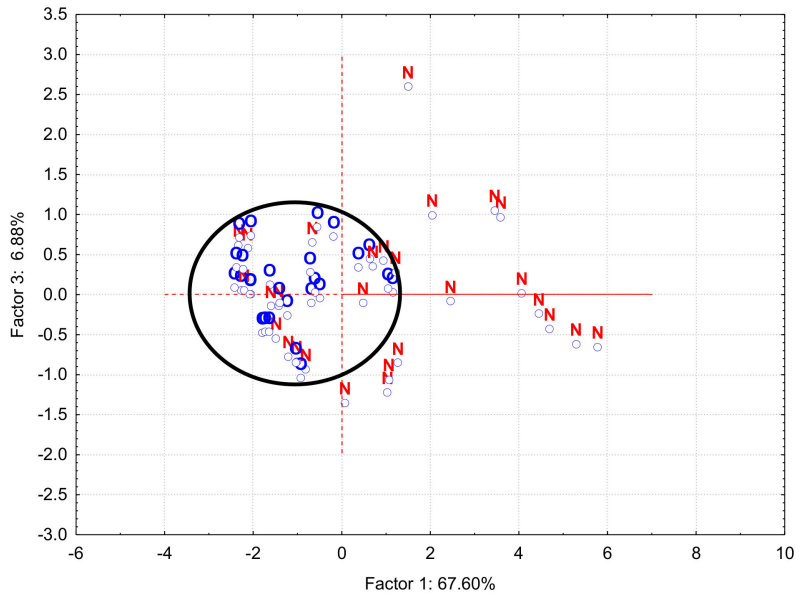

(b)

Figure 2. PCA results for the antioxidant activity and DPPH. kinetics data of all organic ("O" - blue) and non-organic ("N"-red) apple extracts: (a) $P C_{2}$ versus $P C_{1}$ scores plot; (b) $P C_{3}$ versus $P C_{1}$ scores plot.

Taking into account these classifications based on the type of orchard, PCA was applied for every apple variety. Organic "Golden Delicious" apple cases were clearly grouped in the center-right of the both $P C_{2}$ versus $P C_{1}$ and $P C_{3}$ versus $P C_{1}$ scores plots (Figure S13a,b). Only few non-organic cases are located in this region. The classification along $P C_{1}$ is mainly based on all $R S A$ values (with a slight influence for $P C_{2}$ in the case of $R S A\left(1^{\prime}\right)$ and $R S A\left(15^{\prime}\right)$ ), as well as mean DPPH. reaction rates on the first and third time ranges, $\bar{v}_{1}$ and $\bar{v}_{3}$. Almost $93.4 \%$ of the variance of the data are explained by $P C_{1}$ and $P C_{2}$ (Figure S14a,b). Similar results were obtained for the "Florina" variety, where organic samples are located in the center of the scores plots $(94.11 \%$ explained variance for the $P C_{1}$ and $P C_{2}$, Figure $\mathrm{S} 13 \mathrm{c}, \mathrm{d}$ for scores plots, Figure $\mathrm{S} 14 \mathrm{c}, \mathrm{d}$ for loadings plots and eigenvalues of the correlation matrix), as well as for the "Generos" and "Starkrimson" apple varieties, with locations in the center or center-right of the scores plots (Figure S13e-h explains variances of $92.53 \%$ and $97.70 \%$ for the first two PCs, respectively; Figure S14e-h).

PCA approach allows partial differentiation of the organic and non-organic apples, especially through the $\mathrm{DPPH} \cdot$ kinetics parameters. Kinetics for the first time interval of the $\mathrm{DPPH}$. reaction especially influence the $P C_{1}$ (together with $R S A$ parameters), while the kinetic parameters for the next time ranges are important for $P C_{2}$. This discrimination can be due to the different antioxidant composition of the apple, such as the antioxidant compounds with higher reactivity that are more concentrated in organic samples (e.g., ascorbic acid, phenolic compounds with less hindered hydroxyl groups). However, DPPH-apple antioxidant compound interaction involves very complex parallel and consecutive reactions and it is difficult to evaluate such aspects if the study is focused on the specific compounds. These affirmations are sustained by the research on the ascorbic acid, total phenolic and flavonoid, as well as specific antioxidant contents in apples and apple juices of various geographical origin [35]. The ascorbic acid content in such samples ranged from $140 \mathrm{mg} / \mathrm{L}$ in Europe to $247 \mathrm{mg} / \mathrm{L}$ in North America, and from $148 \mathrm{mg} / \mathrm{L}$ in clarified juice to $254 \mathrm{mg} / \mathrm{L}$ for integral apple juice. Chlorogenic acid is the most concentrated in the last type of apple beverage, but all identified antioxidant compound contents vary in wide ranges. These samples were relatively well grouped by PCA, with a significant influence of the chlorogenic acid content. Similar research related to the geographical origin or location of apples was performed for "Golden Delicious" and "Jonagold" varieties, where the same chlorogenic acid was the most concentrated [24,29]. PCA was applied for organic apple 
classification or authentication especially through the aroma compound profile or other organoleptic and image processing parameters $[55,56]$. Regarding the antioxidant activity of organic apples, PCA or PLS were only applied for differentiation of apples subjected to freezing pre-treatments or processing $[31,58]$.

\section{Materials and Methods}

\subsection{Fruits and Chemicals}

Four apple varieties cultivated and/or commercialized in the western region of Romania (year 2019) were considered for this study. Thus, 5 samples of the "Golden Delicious" variety (code " $G d$ ") were obtained from the organic orchard (2 samples harvested from opposite locations of the orchard) and conventional orchards ( 3 samples from which 2 samples were obtained directly from the orchards and 1 sample from the local supermarket). "Florina" apples (code " $\left.F l^{\prime \prime}\right)$ were obtained from the same organic orchard (2 samples) and from conventional orchards ( 1 sample directly from the orchard and 1 sample from the local supermarket). Two samples of the "Generos" variety (code " $G n^{\prime \prime}$ ) were obtained from the above-mentioned organic orchard ( 1 sample) and directly from the conventional orchard (1 sample). Finally, the "Starkrimson" variety (code "Sk") was obtained from the organic orchard (2 samples) and from the local supermarket (1 sample). Codes, description and other information related to the apple samples used in this study are presented in Table 9. The organic orchard is located in western Romania (Şiria, Arad county, $46^{\circ} 16^{\prime} 2^{\prime \prime} \mathrm{N}$, $21^{\circ} 38^{\prime} 18^{\prime \prime} \mathrm{E}$, altitude $109 \mathrm{~m}$ ). Only manure was used as fertilizer and no pesticides were applied. Apples were harvested at the maturity stage and they were of medium size (specific for every variety). Four fruits were used for every sample. Fresh apples were stored at $4{ }^{\circ} \mathrm{C}$ until the solid-liquid extraction, which was performed up to two days after collection.

To determine the antioxidant activity, evaluated by the free radical scavenging activity (RSA), the stable free radical 2,2-diphenyl-1-picrylhydrazyl (DPPH-, $>99 \%$, Merck \& Co., Inc., Kenilworth, NJ, USA) was used. Ethanol (volumetric concentration of $96 \%$, pro analysis grade, Chimopar, Bucharest) was used for the extraction and RSA evaluation. Polyphenols used as standard antioxidant compounds were of high purity as follows: resveratrol $98 \%$ (J \& K Scientific LLC, San Jose, CA, USA) and propyl gallate $\geq 98 \%$ (Sigma-Aldrich Co., St. Louis, MO, USA).

Table 9. Codes and description of the organic and conventional apple samples.

\begin{tabular}{|c|c|c|}
\hline Code & $\begin{array}{l}\text { Organic or Non-Organic } \\
\text { Orchard }{ }^{1}\end{array}$ & Description \\
\hline$G d(s h) \_S R a$ & $O$ & $\begin{array}{c}\text { "Golden Delicious" variety, shell sample "a", harvested from the organic orchard (Şiria, Arad } \\
\text { county, Romania, } 46^{\circ} 16^{\prime} 2^{\prime \prime} \mathrm{N}, 21^{\circ} 38^{\prime} 18^{\prime \prime} \mathrm{E} \text { ) }\end{array}$ \\
\hline$G d(c o) \_S R a$ & $O$ & $\begin{array}{l}\text { "Golden Delicious" variety, core sample "a", harvested from the organic orchard (Şiria, Arad } \\
\text { county, Romania, } 46^{\circ} 16^{\prime} 2^{\prime \prime} \mathrm{N}, 21^{\circ} 38^{\prime} 18^{\prime \prime} \mathrm{E} \text { ) }\end{array}$ \\
\hline$G d(s h) \_S R b$ & $O$ & $\begin{array}{l}\text { "Golden Delicious" variety, shell sample " } \mathrm{b} \text { ", harvested from the organic orchard (Şiria, Arad } \\
\text { county, Romania, } 46^{\circ} 16^{\prime} 2^{\prime \prime} \mathrm{N}, 21^{\circ} 38^{\prime} 18^{\prime \prime} \mathrm{E} \text { ) }\end{array}$ \\
\hline$G d(c o) \_S R b$ & $O$ & $\begin{array}{c}\text { "Golden Delicious" variety, core sample " } \mathrm{b} \text { ", harvested from the organic orchard (Şiria, Arad } \\
\left.\text { county, Romania, } 46^{\circ} 16^{\prime} 2^{\prime \prime} \mathrm{N}, 21^{\circ} 38^{\prime} 18^{\prime \prime} \mathrm{E}\right)\end{array}$ \\
\hline$G d(s h) \_A R$ & $N$ & $\begin{array}{l}\text { "Golden Delicious" variety, shell sample, harvested directly from the conventional orchard (Arad, } \\
\left.\text { Arad county, Romania, } 46^{\circ} 10^{\prime} \mathrm{N}, 21^{\circ} 19^{\prime} \mathrm{E}\right)\end{array}$ \\
\hline$G d(c o) \_A R$ & $N$ & $\begin{array}{l}\text { "Golden Delicious" variety, core sample, harvested directly from the conventional orchard (Arad, } \\
\left.\text { Arad county, Romania, } 46^{\circ} 10^{\prime} \mathrm{N}, 21^{\circ} 19^{\prime} \mathrm{E}\right)\end{array}$ \\
\hline$G d(s h) \_L G$ & $N$ & $\begin{array}{l}\text { "Golden Delicious" variety, shell sample, harvested from the conventional orchard (Lugoj, Timiş } \\
\left.\text { county, Romania, } 45^{\circ} 41^{\prime} 10^{\prime \prime} \mathrm{N}, 21^{\circ} 52^{\prime} 2^{\prime \prime} \mathrm{E}\right)\end{array}$ \\
\hline$G d(c o) \_L G$ & $N$ & $\begin{array}{l}\text { "Golden Delicious" variety, core sample, harvested from the conventional orchard (Lugoj, Timiş } \\
\left.\text { county, Romania, } 45^{\circ} 41^{\prime} 10^{\prime \prime} \mathrm{N}, 21^{\circ} 52^{\prime} 2^{\prime \prime} \mathrm{E}\right)\end{array}$ \\
\hline$G d(s h) \_M K$ & $N$ & $\begin{array}{l}\text { "Golden Delicious" variety, shell sample, purchased from the supermarket (Timişoara, Timiş } \\
\text { county, Romania) }\end{array}$ \\
\hline$G d(c o) \_M K$ & $N$ & $\begin{array}{c}\text { "Golden Delicious" variety, core sample, purchased from the supermarket (Timişoara, Timiş } \\
\text { county, Romania) }\end{array}$ \\
\hline
\end{tabular}


Table 9. Cont.

\begin{tabular}{|c|c|c|}
\hline Code & $\begin{array}{l}\text { Organic or Non-Organic } \\
\text { Orchard }^{1}\end{array}$ & Description \\
\hline$F l(s h) \_S R a$ & $O$ & $\begin{array}{l}\text { "Florina" variety, shell sample "a", harvested from the organic orchard (Şiria, Arad county, } \\
\text { Romania, } 46^{\circ} 16^{\prime} 2^{\prime \prime} \mathrm{N}, 21^{\circ} 38^{\prime} 18^{\prime \prime} \mathrm{E} \text { ) }\end{array}$ \\
\hline$F l(c o) \_S R a$ & $O$ & $\begin{array}{l}\text { "Florina" variety, core sample "a", harvested from the organic orchard (Şiria, Arad county, } \\
\text { Romania, } 46^{\circ} 16^{\prime} 2^{\prime \prime} \mathrm{N}, 21^{\circ} 38^{\prime} 18^{\prime \prime} \mathrm{E} \text { ) }\end{array}$ \\
\hline$F l(s h) \_S R b$ & $O$ & $\begin{array}{l}\text { "Florina" variety, shell sample " } \mathrm{b} \text { ", harvested from the organic orchard (Şiria, Arad county, } \\
\text { Romania, } 46^{\circ} 16^{\prime} 2^{\prime \prime} \mathrm{N}, 21^{\circ} 38^{\prime} 18^{\prime \prime} \mathrm{E} \text { ) }\end{array}$ \\
\hline$F l(c o) \_S R b$ & $O$ & $\begin{array}{l}\text { "Florina" variety, core sample " } \mathrm{b} \text { ", harvested from the organic orchard (Şiria, Arad county, } \\
\left.\text { Romania, } 46^{\circ} 16^{\prime} 2^{\prime \prime} \mathrm{N}, 21^{\circ} 38^{\prime} 18^{\prime \prime} \mathrm{E}\right)\end{array}$ \\
\hline$F l(s h) \_L G$ & $N$ & $\begin{array}{l}\text { "Florina" variety, shell sample, harvested from the conventional orchard (Lugoj, Timiş county, } \\
\left.\text { Romania, } 45^{\circ} 41^{\prime} 10^{\prime \prime} \mathrm{N}, 21^{\circ} 52^{\prime} 2^{\prime \prime} \mathrm{E}\right)\end{array}$ \\
\hline$F l(c o) \_L G$ & $N$ & $\begin{array}{l}\text { "Florina" variety, core sample, harvested from the conventional orchard (Lugoj, Timiş county, } \\
\left.\text { Romania, } 45^{\circ} 41^{\prime} 10^{\prime \prime} \mathrm{N}, 21^{\circ} 52^{\prime} 2^{\prime \prime} \mathrm{E}\right)\end{array}$ \\
\hline$F l(s h) \_M K$ & $N$ & $\begin{array}{c}\text { "Florina" variety, shell sample, purchased from the supermarket (Timişoara, Timiş county, } \\
\text { Romania) }\end{array}$ \\
\hline$F l(c o) \_M K$ & $N$ & $\begin{array}{l}\text { "Florina" variety, core sample, purchased from the supermarket (Timişoara, Timiş county, } \\
\text { Romania) }\end{array}$ \\
\hline$G n(s h) \_S R$ & $O$ & $\begin{array}{l}\text { "Generos" variety, shell sample, harvested from the organic orchard (Şiria, Arad county, Romania, } \\
\left.\qquad 46^{\circ} 16^{\prime} 2^{\prime \prime} \mathrm{N}, 21^{\circ} 38^{\prime} 18^{\prime \prime} \mathrm{E}\right)\end{array}$ \\
\hline$G n(c o) \_S R$ & $O$ & $\begin{array}{l}\text { "Generos" variety, core sample, harvested from the organic orchard (Şiria, Arad county, Romania, } \\
\left.\qquad 46^{\circ} 16^{\prime} 2^{\prime \prime} \mathrm{N}, 21^{\circ} 38^{\prime} 18^{\prime \prime} \mathrm{E}\right)\end{array}$ \\
\hline$G n(s h) \_L G$ & $N$ & $\begin{array}{l}\text { "Generos" variety, shell sample, harvested from the conventional orchard (Lugoj, Timiş county, } \\
\left.\text { Romania, } 45^{\circ} 41^{\prime} 10^{\prime \prime} \mathrm{N}, 21^{\circ} 52^{\prime} 2^{\prime \prime} \mathrm{E}\right)\end{array}$ \\
\hline$G n(c o) \_L G$ & $N$ & $\begin{array}{l}\text { "Generos" variety, core sample, harvested from the conventional orchard (Lugoj, Timiş county, } \\
\left.\text { Romania, } 45^{\circ} 41^{\prime} 10^{\prime \prime} \mathrm{N}, 21^{\circ} 52^{\prime} 2^{\prime \prime} \mathrm{E}\right)\end{array}$ \\
\hline$S k(s h) \_S R a$ & $O$ & $\begin{array}{c}\text { "Starkrimson" variety, shell sample "a", harvested from the organic orchard (Şiria, Arad county, } \\
\left.\text { Romania, } 46^{\circ} 16^{\prime} 2^{\prime \prime} \mathrm{N}, 21^{\circ} 38^{\prime} 18^{\prime \prime} \mathrm{E}\right)\end{array}$ \\
\hline$S k(c o) \_S R a$ & $O$ & $\begin{array}{l}\text { "Starkrimson" variety, core sample "a", harvested from the organic orchard (Şiria, Arad county, } \\
\left.\text { Romania, } 46^{\circ} 16^{\prime} 2^{\prime \prime} \mathrm{N}, 21^{\circ} 38^{\prime} 18^{\prime \prime} \mathrm{E}\right)\end{array}$ \\
\hline$S k(s h) \_S R b$ & $O$ & $\begin{array}{c}\text { "Starkrimson" variety, shell sample " } \mathrm{b} \text { ", harvested from the organic orchard (Şiria, Arad county, } \\
\left.\text { Romania, } 46^{\circ} 16^{\prime} 2^{\prime \prime} \mathrm{N}, 21^{\circ} 38^{\prime} 18^{\prime \prime} \mathrm{E}\right)\end{array}$ \\
\hline$S k(s h) \_M K$ & $N$ & $\begin{array}{c}\text { "Starkrimson" variety, shell sample, purchased from the supermarket (Timişoara, Timiş county, } \\
\text { Romania) }\end{array}$ \\
\hline$S k(c o) \_M K$ & $N$ & $\begin{array}{c}\text { "Starkrimson" variety, core sample, purchased from the supermarket (Timişoara, Timiş county, } \\
\text { Romania) }\end{array}$ \\
\hline
\end{tabular}

\subsection{Obtaining of Apple Extracts}

Both shell and core (abbreviated as "sh" and " $\mathrm{co}^{\prime}$, Table 9) of the fruit were subjected to the extraction and analysis. They were manually separated using a knife. The apple shell had a thickness of 1-2 mm. Fresh samples were immediately milled using a $400 \mathrm{~mL}$ ceramic mortar and weighted for extraction. The solid-liquid extraction was performed under mild conditions (room temperature, in the dark) in order to reduce the thermal and oxidative degradation of antioxidant compounds. Thus, $5.0 \mathrm{~g}$ of ground sample was mixed with $20 \mathrm{~mL}$ of $96 \%$ ethanol in a $250 \mathrm{~mL}$ hermetically sealed extraction flask maintained at $25( \pm 1){ }^{\circ} \mathrm{C}$ in the dark. The mixture was intermittently stirred for $24 \mathrm{~h}$. Then, the extract was filtered at normal pressure using filter paper of $5-8 \mu \mathrm{m}$ pore size and $87 \mathrm{~g} / \mathrm{m}^{2}$ basis weight, washed with $2 \mathrm{~mL}$ of ethanol and centrifuged at $3000 \mathrm{rpm}$ for $10 \mathrm{~min}$ at room temperature using a Heraeus AG centrifuge (Hanau, Germany). After decantation, the apple extract was diluted to $25 \mathrm{~mL}$ with ethanol in order to compare the results. They were stored at $4{ }^{\circ} \mathrm{C}$ until analysis. All extracts were obtained as duplicates (coded as " 1 " and " 2 ").

\subsection{Evaluation of the Radical Scavenging Activity (RSA) by DPPH· Method}

The overall antioxidant activity was monitored for $15 \mathrm{~min}$ by means of the RSA values, both for apple extracts and standard antioxidant compound solutions (resveratrol as natural antioxidant and propyl gallate as synthetic antioxidant). Thus, $0.5 \mathrm{~mL}$ of apple extracts or standard antioxidant solutions at various concentrations were mixed with $2 \mathrm{~mL}$ ethanol and a $0.5 \mathrm{~mL} 0.1 \mathrm{mM}$ DPPH. ethanolic solution in a $10 \mathrm{~mm}$ quartz cuvette (the apple 
extract:DPPH. solution:ethanol volume ratio was 1:1:4). The mixture was immediately sealed and subjected to spectrophotometrical monitoring at $517 \mathrm{~nm}$ for $15 \mathrm{~min}$. A CamSpec M501 UV-Vis spectrophotometer (CamSpec Ltd., Cambridge, UK) was used. Acquisition and handling of the UV-Vis data were performed by the Time Scan Measurement module for evaluation of RSA and DPPH. kinetics, and Wavelength Scan Measurement module for obtaining the DPPH calibration curve, both from UV-Vis Analyst version 4.67 software (CamSpec Ltd., Cambridge, UK). The actual RSA values were obtained according to Equation (3), where $A_{t=0}$ and $A_{t}$ stand for absorbance at the start of the measurement $(t=0 \mathrm{~s})$ and the time $t$.

$$
R S A=\frac{A_{t=0}-A_{t}}{A_{t=0}} \cdot 100
$$

\subsection{Evaluation of the DPPH. Kinetics}

Due to the complex mixture of the apple extracts, the DPPH - interaction involves many antioxidant compounds in parallel, consecutive and competitive chemical reactions. They especially are phenolic and enolic compounds (e.g., flavonoid glycosides and ascorbic acid). As a consequence, it is difficult to evaluate the DPPH. kinetics in relation with a specific compound. This was the reason to use the mean DPPH reaction rates for characteristic time ranges from the Concentration versus Time plots. Only DPPH. has significant absorbance at $517 \mathrm{~nm}$ in the apple extract-DPPH. solution mixture. During the reaction, DPPH. is converted into the neutral DPPH-H compound (2,2-diphenyl-1-pycrylhydrazine), which as significant absorbance at wavelengths lower than $450 \mathrm{~nm}$. Neither antioxidant compounds in apple extracts, nor the reaction products have absorbance at $517 \mathrm{~nm}$. Thus, the variation of the absorbance at $517 \mathrm{~nm}$ can be converted as the variance of DPPH. concentration in time. The Concentration versus Absorbance calibration curve for DPPH. solutions in the range of 0-300 $\mu \mathrm{M}$ was obtained with statistically significant parameters $\left(n=5, r^{2}=0.999\right.$ and $p<0.000001)$. The DPPH. concentration in Equation (4) is expressed as $\mu \mathrm{M}$ and the absorbance $A$ is determined at $517 \mathrm{~nm}$. Generally, the Concentration versus Time plots reveal three pseudo-linear ranges. In order to compare the DPPH. kinetics results, these time ranges were set as $0-30 \mathrm{~s}$ for $\Delta t_{1}, 30-180 \mathrm{~s}$ for $\Delta t_{2}$ and 180-900 s for $\Delta t_{3}$. The variation (decrease) in the DPPH. concentration for these three time ranges allows determination of the mean DPPH. reaction rate (Equation (5)) as the drift of the linear equation resulted from the Concentration versus Time correlation for every time range. In order to easier compare the DPPH. reaction rate values, they were expressed in $\mu \mathrm{M} / \mathrm{s}$.

$$
\begin{aligned}
C_{D P P H} & =159.58( \pm 2.80) \cdot A \\
\bar{v}_{1-3} & =-\frac{\Delta C_{D P P H(1-3)}}{\Delta t_{1-3}}
\end{aligned}
$$

\subsection{Statistical, Correlational and Principal Component Analyses}

All results were presented as means ( \pm standard deviation, $S D)$, obtained using the Basic Statistics $\mathcal{E}$ Tables and One-way ANOVA modules in Statistica 7.1 software (StatSoft, Inc., Tulsa, OK, USA). The same One-way ANOVA module was used for evaluating the significant differences between values by means of Tukey's HSD (honest significant difference) test. Linear correlations for the DPPH. calibration curve, for evaluation of mean DPPH. reaction rates, as well as for the correlation between antioxidant activity and DPPH. kinetics parameters, were performed using Multiple Linear Regression module in the same Statistica package. Linear regression equations were statistically evaluated by means of the Pearson correlation coefficient, $r$, or determination coefficient, $r^{2}, F$-Fisher and $p$-values, standard error of estimate, $s$, and standard errors for linear regression coefficients. The confidence limit and significance level were 0.95 and 0.05 , respectively. Discrimination between sample types was based on the overall antioxidant activity and DPPH. kinetics parameter values. The data matrix was subjected to principal component analysis (PCA), which is a powerful multivariate statistical analysis technique that allows extraction of the useful information 
from a large dataset. In the DPPH. kinetics-PCA approach all samples were considered as cases while RCA and mean DPPH. reaction rates were set as variables. The scores and loadings plots provide information about the grouping of cases and the influence of variables to the classification, respectively. PCA was performed using a cross-validation method and centered data by means of the Principal Components $\mathcal{E}$ Classification Analysis module in the same Statistica 7.1 package.

\section{Conclusions}

The DPPH. kinetics-PCA approach was for the first time performed for discrimination between organic and non-organic fruits. This approach was successfully applied for organic and non-organic "Golden Delicious", "Florina", "Generos" and "Starkrimson" apple varieties cultivated in the western region of Romania. All apple samples reveal high antioxidant activity, according to the DPPH. method. However, DPPH. kinetics provide more important information that can be correlated with the type of orchard and the part of the fruit. The mean DPPH. reaction rates at the start of the reaction with the complex mixture of antioxidant compounds from apples are higher in organic samples, more evident for the outer part of the fruit. On the contrary, the apple cores have significant activity even at the later time, providing a prolonged antioxidant effect. As a conclusion, there are different antioxidant compound profiles in organic and non-organic apples, as well as according to the fruit part, which can be used for evaluating the quality of fruits through a relatively simple and fast combined technique.

Supplementary Materials: The following are available online at https:/ / www.mdpi.com/article/10 $.3390 /$ plants10091957/s1, Figure S1: Variation of the radical scavenging activity $(R S A \%)$ during the spectrophotometric monitoring for the extracts obtained from the "Golden Delicious" apple varieties in the presence of the DPPH. solution: (a) organic shell and core apple extracts, Gd(sh)_SRa and $G d(c o) \_S R a$; (b) organic shell and core apple extracts, $G d(s h) \_S R b$ and $G d(c o) \_S R b$; (c) non-organic shell and core apple extracts, $G d(s h) \_A R$ and $G d(c o) \_A R ;(\mathrm{d})$ non-organic shell and core apple extracts, $G d(s h) \_L G$ and $G d(c o) \_L G$; (e) non-organic shell and core apple extracts, $G d(s h) \_M K$ and $G d(c o) \_M K$ (all determinations are presented as duplicates "1" and "2"), Figure S2: Variation of the radical scavenging activity (RSA\%) during the spectrophotometric monitoring for the extracts obtained from the "Florina" apple varieties in the presence of the DPPH. solution: (a) organic shell and core apple extracts, $F l(s h) \_S R a$ and $F l(c o) \_S R a ;(b)$ organic shell and core apple extracts, $F l(s h) \_S R b$ and $F l(c o) \_S R b$; (c) non-organic shell and core apple extracts, $F l(s h) \_L G$ and $F l(c o) \_L G$; (d) non-organic shell and core apple extracts, $F l(s h) \_M K$ and $F l(c o) \_M K$ (all determinations are presented as duplicates " 1 " and " 2 "), Figure S3: Variation of the radical scavenging activity (RSA\%) during the spectrophotometric monitoring for the extracts obtained from the "Generos" apple varieties in the presence of the DPPH. solution: (a) organic shell and core apple extracts, Gn(sh)_SR and Gn(co)_SR; (b) non-organic shell and core apple extracts, $G n(s h) \_L G$ and $G n(c o) \_L G$ (all determinations are presented as duplicates " 1 " and " 2 "), Figure S4: Variation of the radical scavenging activity (RSA\%) during the spectrophotometric monitoring for the extracts obtained from the "Starkrimson" apple varieties in the presence of the DPPH. solution: (a) organic shell and core apple extracts, Sk(sh)_SRa and $S k(c o) \_S R a ;(b)$ organic shell apple extracts, $S k(s h) \_S R b$; (c) non-organic shell and core apple extracts, $S k(s h) \_M K$ and $S k(c o) \_M K$ (all determinations are presented as duplicates "1" and "2"), Table S1: Radical scavenging activity $(R S A \%)$ at various times of monitoring for the standard antioxidant compound solutions ( $R v_{-} 1 \mathrm{mM} / 0.2 \mathrm{mM} / 0.1 \mathrm{mM}$-resveratrol solutions at concentrations of $1 \mathrm{mM} / 0.2$ $\mathrm{m} / 0.1 \mathrm{mM}$; PG_0.2 mM-propyl gallate solution at a concentration of $0.2 \mathrm{mM}$ ). Values are expressed as means ( \pm standard deviation, SD), Table S2: Significance $p$-levels from the Tukey HSD test (honest significant difference) for the antioxidant activity of "Golden Delicious" apple extracts (RSA—radical scavenging activity, \%, at $1 \mathrm{~min}$; organic shell apple extracts: $G d(s h) \_S R a$ and $G d(s h) \_S R b$; organic core apple extracts: $G d(c o) \_S R a$ and $G d(c o) \_S R b$; non-organic shell apple extracts: $G d(s h) \_A R, G d(s h) \_L G$ and $G d(s h) \_M K$; non-organic core apple extracts: $G d(c o) \_A R, G d(c o) \_L G$ and $\left.G d(c o) \_M K\right)$. p -level values lower than 0.05 are in bold, Table S3: Significance $p$-levels from the Tukey HSD test (honest significant difference) for the antioxidant activity of "Golden Delicious" apple extracts (RSA-radical scavenging activity, \%, at 3 min; organic shell apple extracts: $G d(s h) \_S R a$ and $G d(s h) \_S R b$; organic core apple extracts: $G d(c o) \_S R a$ and $G d(c o) \_S R b$; non-organic shell apple extracts: $G d(s h) \_A R, G d(s h) \_L G$ 
and $G d(s h) \_M K$; non-organic core apple extracts: $G d(c o) \_A R, G d(c o) \_L G$ and $\left.G d(c o) \_M K\right)$. p-level values lower than 0.05 are in bold, Table S4: Significance $p$-levels from the Tukey HSD test (honest significant difference) for the antioxidant activity of "Golden Delicious" apple extracts (RSA-radical scavenging activity, \%, at $5 \mathrm{~min}$; organic shell apple extracts: $G d(s h) \_S R a$ and $G d(s h) \_S R b$; organic core apple extracts: $G d(c o) \_S R a$ and $G d(c o) \_S R b$; non-organic shell apple extracts: $G d(s h) \_A R, G d(s h) \_L G$ and $G d(s h) \_M K$; non-organic core apple extracts: $G d(c o) \_A R, G d(c o) \_L G$ and $\left.G d(c o) \_M K\right)$. p-level values lower than 0.05 are in bold, Table S5: Significance $p$-levels from the Tukey HSD test (honest significant difference) for the antioxidant activity of "Golden Delicious" apple extracts (RSA-radical scavenging activity, \%, at $15 \mathrm{~min}$; organic shell apple extracts: $G d(s h) \_S R a$ and $G d(s h) \_S R b$; organic core apple extracts: $G d(c o) \_S R a$ and $G d(c o) \_S R b$; non-organic shell apple extracts: $G d(s h) \_A R$, $G d(s h) \_L G$ and $G d(s h) \_M K$; non-organic core apple extracts: $G d(c o) \_A R, G d(c o) \_L G$ and $\left.G d(c o) \_M K\right)$. $p$-level values lower than 0.05 are in bold, Table S6: Significance $p$-levels from the Tukey HSD test (honest significant difference) for the antioxidant activity of "Florina" apple extracts (RSA—radical scavenging activity, \%, at $1 \mathrm{~min}$; organic shell apple extracts: $F l(s h) \_S R a$ and $F l(s h) \_S R b$; organic core apple extracts: $F l(c o) \_S R a$ and $F l(c o) \_S R b$; non-organic shell apple extracts: $F l(s h) \_L G$ and $F l(s h) \_M K$; non-organic core apple extracts: $F l(c o) \_L G$ and $\left.F l(c o) \_M K\right)$. $p$-level values lower than 0.05 are in bold, Table S7: Significance $p$-levels from the Tukey HSD test (honest significant difference) for the antioxidant activity of "Florina" apple extracts ( $R S A$-radical scavenging activity, \%, at 3 min; organic shell apple extracts: $F l(s h) \_S R a$ and $F l(s h) \_S R b$; organic core apple extracts: $F l(c o) \_S R a$ and $F l(c o) \_S R b$; non-organic shell apple extracts: $F l(s h) \_L G$ and $F l(s h) \_M K$; non-organic core apple extracts: $F l(c o) \_L G$ and $\left.\mathrm{Fl}(\mathrm{co})_{-} \mathrm{MK}\right)$. $p$-level values lower than 0.05 are in bold, Table S8: Significance $p$-levels from the Tukey HSD test (honest significant difference) for the antioxidant activity of "Florina" apple extracts (RSA—radical scavenging activity, \%, at $5 \mathrm{~min}$; organic shell apple extracts: $F l(s h) \_S R a$ and $F l(s h) \_S R b$; organic core apple extracts: $F l(c o) \_S R a$ and $F l(c o) \_S R b$; non-organic shell apple extracts: $F l(s h) \_L G$ and $F l(s h) \_M K$; non-organic core apple extracts: $F l(c o) \_L G$ and $\left.F l(c o) \_M K\right)$. $p$-level values lower than 0.05 are in bold, Table S9: Significance $p$-levels from the Tukey HSD test (honest significant difference) for the antioxidant activity of "Florina" apple extracts (RSA-radical scavenging activity, \%, at 15 min; organic shell apple extracts: $F l(s h) \_S R a$ and $F l(s h) \_S R b$; organic core apple extracts: $F l(c o) \_S R a$ and $F l(c o) \_S R b$; non-organic shell apple extracts: $F l(s h) \_L G$ and $F l(s h) \_M K$; non-organic core apple extracts: $F l(c o) \_L G$ and $\left.F l(c o) \_M K\right)$. p -level values lower than 0.05 are in bold, Table S10: Significance $p$-levels from the Tukey HSD test (honest significant difference) for the antioxidant activity of "Generos" apple extracts (RSA—radical scavenging activity, \%, at $1 \mathrm{~min}$; organic shell apple extract: $G n(s h) \_S R$; organic core apple extract: $G n(c o) \_S R$; non-organic shell apple extract: $G n(s h) \_L G$; non-organic core apple extract: $G n(c o) L G)$. $p$-level values lower than 0.05 are in bold, Table S11: Significance $p$-levels from the Tukey HSD test (honest significant difference) for the antioxidant activity of "Generos" apple extracts (RSA—radical scavenging activity, \%, at 3 min; organic shell apple extract: Gn(sh)_SR; organic core apple extract: $G n(c o) \_S R$; non-organic shell apple extract: $G n(s h) \_L G$; non-organic core apple extract: $\left.G n(c o) \_L G\right)$. $p$-level values lower than 0.05 are in bold, Table S12: Significance $p$-levels from the Tukey HSD test (honest significant difference) for the antioxidant activity of "Generos" apple extracts (RSA—radical scavenging activity, \%, at $5 \mathrm{~min}$; organic shell apple extract: $G n(s h) \_S R$; organic core apple extract: $G n(c o) \_S R$; non-organic shell apple extract: $G n(s h) \_L G$; non-organic core apple extract: $G n(c o) L G$ ). $p$-level values lower than 0.05 are in bold, Table S13: Significance $p$-levels from the Tukey HSD test (honest significant difference) for the antioxidant activity of "Generos" apple extracts (RSA—radical scavenging activity, \%, at $15 \mathrm{~min}$; organic shell apple extract: $G n(s h) \_S R$; organic core apple extract: $G n(c o) \_S R$; non-organic shell apple extract: $G n(s h) \_L G$; non-organic core apple extract: $G n(c o) L G)$. $p$-level values lower than 0.05 are in bold, Table S14: Significance $p$-levels from the Tukey HSD test (honest significant difference) for the antioxidant activity of "Starkrimson" apple extracts (RSA—radical scavenging activity, \%, at $1 \mathrm{~min}$; organic shell apple extracts: $S k(s h) \_S R a$ and $S k(s h) \_S R b$; organic core apple extract: $S k(c o) \_S R a$; non-organic shell apple extract: $S k(s h) \_M K$; non-organic core apple extract: $\left.S k(c o) \_L G\right)$. $p$-level values lower than 0.05 are in bold, Table S15: Significance $p$-levels from the Tukey HSD test (honest significant difference) for the antioxidant activity of "Starkrimson" apple extracts (RSA—radical scavenging activity, \%, at 3 min; organic shell apple extracts: $S k(s h) \_S R a$ and $S k(s h) \_S R b$; organic core apple extract: $S k(c o) \_S R a$; non-organic shell apple extract: $S k(s h) \_M K$; non-organic core apple extract: $\left.S k(c o) \_L G\right)$. $p$-level values lower than 0.05 are in bold, Table S16: Significance $p$-levels from the Tukey HSD test (honest significant difference) for the antioxidant activity of "Starkrimson" apple extracts (RSA-radical scavenging activity, \%, at 5 min; organic shell apple extracts: $S k(s h) \_S R a$ and $S k(s h) \_S R b$; organic core apple extract: $S k(c o) \_S R a$; 
non-organic shell apple extract: $S k(s h) \_M K$; non-organic core apple extract: $\left.S k(c o) \_L G\right)$. $p$-level values lower than 0.05 are in bold, Table S17: Significance $p$-levels from the Tukey HSD test (honest significant difference) for the antioxidant activity of "Starkrimson" apple extracts (RSA-radical scavenging activity, \%, at $15 \mathrm{~min}$; organic shell apple extracts: $S k(s h) \_S R a$ and $S k(s h) \_S R b$; organic core apple extract: $S k(c o) \_S R a$; non-organic shell apple extract: $S k(s h) \_M K$; non-organic core apple extract: $\left.S k(c o) \_L G\right)$. $p$-level values lower than 0.05 are in bold, Figure S5: Variation of the DPPH. concentration during the reaction with antioxidant compounds from the extracts obtained from: (a) organic shell and core "Golden Delicious" apple variety $\left(G d(s h) \_S R a\right.$ and $\left.G d(c o) \_S R a\right)$; (b) non-organic shell and core "Golden Delicious" apple variety $\left(G d(s h) \_L G\right.$ and $\left.L G(c o) \_A R\right)$; (c) non-organic shell and core "Golden Delicious" apple variety $\left(G d(s h) \_M K\right.$ and $\left.G d(c o) \_M K\right)$ (all determinations are presented as duplicates " 1 " and " 2 "), Figure S6: Variation of the DPPH. concentration during the reaction with antioxidant compounds from the extracts obtained from: (a) organic shell and core "Florina" apple variety $\left(F l(s h) \_S R b\right.$ and $\left.F l(c o) \_S R b\right)$; (b) non-organic shell and core "Florina" apple variety $\left(F l(s h) \_M K\right.$ and $\left.F l(c o) \_M K\right)$; (c) organic shell "Starkrimson" apple variety $\left(S k(s h) \_S R b\right)$ (all determinations are presented as duplicates " 1 " and "2"), Table S18: Values of the mean DPPH. reaction rates $\left(\bar{v}_{1}, \bar{v}_{2}\right.$ and $\bar{v}_{3}$ ) for the standard antioxidant compound solutions (Rv_1 mM/0.2 mM/0.1 mMresveratrol solutions at concentrations of $1 \mathrm{mM} / 0.2 \mathrm{~m} / 0.1 \mathrm{mM} ; P G \_0.2 \mathrm{mM}$-propyl gallate solution at a concentration of $0.2 \mathrm{mM}$ ). Values are expressed as means ( \pm standard deviation, SD), Table S19: Significance $p$-levels from the Tukey HSD test (honest significant difference) for the DPPH. reaction rate on the $\Delta t_{1}=0-30 \mathrm{~s}$ in the presence of "Golden Delicious" apple extracts $\left(\bar{v}_{1}, \mu \mathrm{M} / \mathrm{s}\right.$; organic shell apple extracts: $G d(s h) \_S R a$ and $G d(s h) \_S R b$; organic core apple extracts: $G d(c o) \_S R a$ and $G d(c o) \_S R b$; non-organic shell apple extracts: $G d(s h) \_A R, G d(s h) \_L G$ and $G d(s h) \_M K$; non-organic core apple extracts: $G d(c o) \_A R, G d(c o) \_L G$ and $\left.G d(c o) \_M K\right)$. $p$-level values lower than 0.05 are in bold, Table S20: Significance $p$-levels from the Tukey HSD test (honest significant difference) for the DPPH. reaction rate on the $\Delta t_{2}=30-180 \mathrm{~s}$ in the presence of "Golden Delicious" apple extracts $\left(\bar{v}_{2}, \mu \mathrm{M} / \mathrm{s}\right.$; organic shell apple extracts: $G d(s h) \_S R a$ and $G d(s h) \_S R b$; organic core apple extracts: $G d(c o) \_S R a$ and $G d(c o) \_S R b$; non-organic shell apple extracts: $G d(s h) \_A R, G d(s h) \_L G$ and $G d(s h) \_M K$; non-organic core apple extracts: $G d(c o) \_A R, G d(c o) \_L G$ and $\left.G d(c o) \_M K\right)$. $p$-level values lower than 0.05 are in bold, Table S21: Significance $p$-levels from the Tukey HSD test (honest significant difference) for the DPPH. reaction rate on the $\Delta t_{3}=180-900 \mathrm{~s}$ in the presence of "Golden Delicious" apple extracts $\left(\bar{v}_{3}, \mu \mathrm{M} / \mathrm{s}\right.$; organic shell apple extracts: $G d(s h) \_S R a$ and $G d(s h) \_S R b$; organic core apple extracts: $G d(c o) \_S R a$ and $G d(c o) \_S R b$; non-organic shell apple extracts: $G d(s h) \_A R, G d(s h) \_L G$ and $G d(s h) \_M K$; non-organic core apple extracts: $G d(c o) \_A R, G d(c o) \_L G$ and $\left.G d(c o) \_M K\right)$. $p$-level values lower than 0.05 are in bold, Table S22: Significance $p$-levels from the Tukey HSD test (honest significant difference) for the DPPH. reaction rate on the $\Delta t_{1}=0-30 \mathrm{~s}$ in the presence of "Florina" apple extracts $\left(\bar{v}_{1}, \mu \mathrm{M} / \mathrm{s}\right.$; organic shell apple extracts: $F l(s h) \_S R a$ and $F l(s h) \_S R b$; organic core apple extracts: $F l(c o) \_S R a$ and $F l(c o) \_S R b$; non-organic shell apple extracts: $F l(s h) \_L G$ and $F l(s h) \_M K$; non-organic core apple extracts: $F l(c o) \_L G$ and $\left.F l(c o) \_K K\right)$. $p$-level values lower than 0.05 are in bold, Table S23: Significance $p$-levels from the Tukey HSD test (honest significant difference) for the DPPH. reaction rate on the $\Delta t_{3}=30-180 \mathrm{~s}$ in the presence of "Florina" apple extracts $\left(\bar{v}_{2}, \mu \mathrm{M} / \mathrm{s}\right.$; organic shell apple extracts: $F l(s h) \_S R a$ and $F l(s h) \_S R b$; organic core apple extracts: $F l(c o) \_S R a$ and $F l(c o) \_S R b$; non-organic shell apple extracts: $F l(s h) \_L G$ and $F l(s h) \_M K$; non-organic core apple extracts: $F l(c o) \_L G$ and $\left.F l(c o) \_M K\right)$. p-level values lower than 0.05 are in bold, Table S24: Significance $p$-levels from the Tukey HSD test (honest significant difference) for the DPPH. reaction rate on the $\Delta t_{3}=180-900 \mathrm{~s}$ in the presence of "Florina" apple extracts $\left(\bar{v}_{3}, \mu \mathrm{M} / \mathrm{s}\right.$; organic shell apple extracts: $F l(s h) \_S R a$ and $F l(s h) \_S R b$; organic core apple extracts: $F l(c o) \_S R a$ and $F l(c o) \_S R b$; non-organic shell apple extracts: $F l(s h) \_L G$ and $F l(s h) \_M K$; non-organic core apple extracts: $F l(c o) \_L G$ and $\left.F l(c o) \_M K\right)$. $p$-level values lower than 0.05 are in bold, Table S25: Significance $p$-levels from the Tukey HSD test (honest significant difference) for the DPPH. reaction rate on the $\Delta t_{1}=0-30 \mathrm{~s}$ in the presence of "Generos" apple extracts $\left(\bar{v}_{1}, \mu \mathrm{M} / \mathrm{s}\right.$; organic shell apple extract: $G n(s h) \_S R$; organic core apple extract: $G n(c o) \_S R$; non-organic shell apple extract: $G n(s h) \_L G$; non-organic core apple extract: $G n(c o) L G)$. $p$-level values lower than 0.05 are in bold, Table S26: Significance $p$-levels from the Tukey HSD test (honest significant difference) for the DPPH. reaction rate on the $\Delta t_{2}=30-180 \mathrm{~s}$ in the presence of "Generos" apple extracts $\left(\bar{v}_{2}, \mu \mathrm{M} / \mathrm{s}\right.$; organic shell apple extract: $G n(s h) \_S R$; organic core apple extract: $G n(c o) \_S R$; non-organic shell apple extract: $G n(s h) \_L G$; non-organic core apple extract: $G n(c o) L G)$. $p$-level values lower than 0.05 are in bold, Table S27: Significance $p$-levels from the Tukey HSD test (honest significant difference) for the DPPH. reaction rate on the $\Delta t_{3}=180-900 \mathrm{~s}$ in the presence of "Generos" apple extracts $\left(\bar{v}_{3}, \mu \mathrm{M} / \mathrm{s}\right.$; organic shell 
apple extract: $G n(s h) \_S R$; organic core apple extract: $G n(c o) \_S R$; non-organic shell apple extract: $G n(s h) \_L G$; non-organic core apple extract: $G n(c o) L G$ ). $p$-level values lower than 0.05 are in bold, Table S28: Significance $p$-levels from the Tukey HSD test (honest significant difference) for the DPPH. reaction rate on the $\Delta t_{1}=0-30 \mathrm{~s}$ in the presence of "Starkrimson" apple extracts $\left(\bar{v}_{1}, \mu \mathrm{M} / \mathrm{s}\right.$; organic shell apple extracts: $S k(s h) \_S R a$ and $S k(s h) \_S R b$; organic core apple extract: $S k(c o) \_S R a$; non-organic shell apple extract: $S k(s h) \_M K$; non-organic core apple extract: $\left.S k(c o) \_M K\right)$. p -level values lower than 0.05 are in bold, Table S29: Significance $p$-levels from the Tukey HSD test (honest significant difference) for the DPPH. reaction rate on the $\Delta t_{2}=30-180 \mathrm{~s}$ in the presence of "Starkrimson" apple extracts $\left(\bar{v}_{2}, \mu \mathrm{M} / \mathrm{s}\right.$; organic shell apple extracts: $S k(s h) \_S R a$ and $S k(s h) \_S R b$; organic core apple extract: $S k(c o) \_S R a$; non-organic shell apple extract: $S k(s h) \_M K$; non-organic core apple extract: $\left.S k(c o) \_M K\right)$. $p$-level values lower than 0.05 are in bold, Table S30: Significance $p$-levels from the Tukey HSD test (honest significant difference) for the DPPH. reaction rate on the $\Delta t_{3}=180-900 \mathrm{~s}$ in the presence of "Starkrimson" apple extracts $\left(\bar{v}_{3}, \mu \mathrm{M} / \mathrm{s}\right.$; organic shell apple extracts: $S k(s h) \_S R a$ and $S k(s h) \_S R b$; organic core apple extract: $S k(c o) \_S R a$; non-organic shell apple extract: $S k(s h) \_M K$; non-organic core apple extract: $\left.S k(c o) \_M K\right)$. $p$-level values lower than 0.05 are in bold, Figure S7: Correlations between mean DPPH reaction rate for the first time range of 0-30 s, $\bar{v}_{1}$, and antioxidant activity, $R S A$, at various times for all apple extracts. (a) $R S A$ at $1 \mathrm{~min}$; (b) $R S A$ at $3 \mathrm{~min}$; (c) $R S A$ at $5 \mathrm{~min}$; (d) RSA at $15 \mathrm{~min}$, Figure S8: Representative dependences between the mean DPPH. reaction rates for the second and third time ranges of 30-180 s and 180-900 s ( $\bar{v}_{2}$ and $\left.\bar{v}_{3}\right)$, and antioxidant activity, $R S A$, at various times for all apple extracts. These correlations are not statistically significant. (a) $\bar{v}_{2}$ versus $R S A$ at $1 \mathrm{~min}$; (b) $\bar{v}_{2}$ versus $R S A$ at $15 \mathrm{~min}$; (c) $\bar{v}_{3}$ versus $R S A$ at $1 \mathrm{~min}$, Figure S9: Representative correlations between mean $\mathrm{DPPH}$. reaction rates for the first and third time ranges (0-30 s and 180-900 s, $\bar{v}_{1}$ and $\bar{v}_{3}$ ), and antioxidant activity, RSA, at various times for all organic apple extracts. (a) $\bar{v}_{1}$ versus $R S A$ at $1 \mathrm{~min}$; (a) $\bar{v}_{3}$ versus $R S A$ at $1 \mathrm{~min}$, Equations (S1)-(S4): Linear correlation between antioxidant and DPPH. kinetic parameters and classical analysis parameters for all apple core samples, Equations (S5)-(S9): Linear correlation between antioxidant and DPPH. kinetic parameters and classical analysis parameters for organic apple core samples, Figure S10: PCA results for the antioxidant activity and $\mathrm{DPPH}$. kinetics data of all organic and non-organic apple extracts by variety ("Golden Delicious"—“Gd", orange, "Florina" — " $F l^{\prime \prime}$, green, "Generos"—“ $G n^{\prime \prime}$, turquoise, "Starkrimson"- “Sk", red): (a) $P C_{2}$ versus $P C_{1}$ scores plot; (b) $P C_{2}$ versus $P C_{1}$ loadings plot, Figure S11: PCA results for the antioxidant activity and DPPH. kinetics data of all organic and non-organic apple extracts by variety ("Golden Delicious"- “ $G d^{\prime \prime}$, orange, "Florina" - " $F l^{\prime \prime}$, green, "Generos"—“Gn", turquoise, "Starkrimson"—“Sk", red): (a) $P C_{3}$ versus $P C_{1}$ scores plot; (b) $P C_{3}$ versus $P C_{1}$ loadings plot; (c) eigenvalues of the correlation matrix, Figure S12: PCA results for the antioxidant activity and $\mathrm{DPPH}$ - kinetics data of all organic and non-organic apple extracts by the fruit part (shell—“ "S", red, and core- “ $C$ ", blue): (a) $P C_{2}$ versus $P C_{1}$ scores plot; (b) $P C_{3}$ versus $P C_{1}$ scores plot, Figure S13: PCA results for the antioxidant activity and DPPH k kinetics data of organic (" $\mathrm{O}^{\prime \prime-~}$ blue) and non-organic ("N" $N$-red) apple extracts: (a) $P C_{2}$ versus $P C_{1}$ scores plot for the "Golden Delicious" apple variety; (b) (a) $P C_{3}$ versus $P C_{1}$ scores plot for the "Golden Delicious" apple variety; (c) $P C_{2}$ versus $P C_{1}$ scores plot for the "Florina" apple variety; (d) $P C_{3}$ versus $P C_{1}$ scores plot for the "Florina" apple variety; (e) $P C_{2}$ versus $P C_{1}$ scores plot for the "Generos" apple variety; (f) $P C_{3}$ versus $P C_{1}$ scores plot for the "Generos" apple variety; $(\mathrm{g}) P C_{2}$ versus $P C_{1}$ scores plot for the "Starkrimson" apple variety; (h) $P C_{3}$ versus $P C_{1}$ scores plot for the "Starkrimson" apple variety, Figure S14: PCA results for the antioxidant activity and $\mathrm{DPPH}$. kinetics data of organic and non-organic apple extracts: (a) $P C_{2}$ versus $P C_{1}$ loadings plot for the "Golden Delicious" apple variety; (b) eigenvalues of the correlation matrix for the "Golden Delicious" apple variety; (c) $P C_{2}$ versus $P C_{1}$ loadings plot for the "Florina" apple variety; (d) eigenvalues of the correlation matrix for the "Florina" apple variety; (e) $P C_{2}$ versus $P C_{1}$ loadings plot for the "Generos" apple variety; (f) eigenvalues of the correlation matrix for the "Generos" apple variety; $(\mathrm{g}) P C_{2}$ versus $P C_{1}$ loadings plot for the "Starkrimson" apple variety; (h) eigenvalues of the correlation matrix for the "Starkrimson" apple variety.

Author Contributions: Conceptualization, O.A.I., M.B., N.G.H. and D.I.H.; methodology, N.G.H. and D.I.H.; formal analysis, N.G.H. and D.I.H.; investigation, A.C.I., D.G., I.D. (Ionuţ Dascălu), G.S.B., I.D. (Ioan David), N.G.H. and D.I.H.; resources, O.A.I., M.B. and N.G.H.; writing-original draft preparation, O.A.I., M.B., I.D. (Ioan David), N.G.H. and D.I.H.; writing-review and editing, O.A.I., M.B., I.D. (Ioan David), N.G.H. and D.I.H.; supervision, N.G.H. and D.I.H.; project administration, 
O.A.I., M.B., N.G.H. and D.I.H. All authors have read and agreed to the published version of the manuscript.

Funding: This research received no external funding.

Institutional Review Board Statement: Not applicable.

Informed Consent Statement: Not applicable.

Data Availability Statement: Not applicable.

Acknowledgments: Authors want to thank Simona Funar-Timofei (“Coriolan Drăgulescu” Institute of Chemistry, Romanian Academy) for the help with Statistica 7.1 software.

Conflicts of Interest: The authors declare no conflict of interest.

\section{References}

1. Simmonds, M.S.J.; Howes, M.-J.R. Profile of compounds in different cultivars of apple (Malus $x$ domestica). In Nutritional Composition of Fruit Cultivars; Simmonds, M.S.J., Preedy, V.R., Eds.; Elsevier Inc.: London, UK, 2016; pp. 1-18.

2. FAOSTAT. Crops and Livestock Products; Food and Agriculture Organization: Rome, Italy, 2021.

3. Bogdănescu, D.; Bordean, D.-M.; Poiană, M.A.; Hădărugă, N.; Tătaru, O.; Riviş, A. Characterization of the main Romanian apple varieties based on $\mathrm{pH}$, refractometric index and moisture content. J. Hortic. For. Biotechnol. 2018, 22, 95-99.

4. Soare, E.; Chiurciu, I.-A. Trends in the production and marketing of apples in Romania. Sci. Pap. Ser. Manag. Econ. Eng. Agric. Rural Dev. 2018, 18, 465-472.

5. DeEll, J.R. Pome fruits: Apple quality and storage. In Controlled and Modified Atmospheres for Fresh and Fresh-Cut Produce; Gil, M.I., Beaudry, R., Eds.; Elsevier Inc.: London, UK, 2020; pp. 293-298. [CrossRef]

6. Lu, Y.; Lu, R. Quality evaluation of apples. In Computer Vision Technology for Food Quality Evaluation; Sun, D.-W., Ed.; Elsevier Inc.: London, UK, 2016; pp. 273-304.

7. Massini, L.; Rico, D.; Martin-Diana, A.B. Quality attributes of apple juice: Role and effect of phenolic compounds. In Fruit Juices; Rajauria, G., Tiwari, B.K., Eds.; Elsevier Inc.: London, UK, 2018; pp. 45-57. [CrossRef]

8. Mühlbauer, W.; Müller, J. Apple (Malus domestica Borkh.). In Drying Atlas: Drying Kinetics and Quality of Agricultural Products; Elsevier Inc.: London, UK, 2020; pp. 259-268. [CrossRef]

9. Peck, G.M.; Merwin, I.A. A Grower's Guide to Organic Apples; NYS IPM Publication No. 223; New York State Department of Agriculture and Markets: New York, NY, USA, 2009; p. 72.

10. Moruju, G.; Serboiu, L.; Stanciu, G.; Serboiu, A. Apple Tree (Malus pumila L. var domestica) Variety Named “Generos". Patent RO87692 (A2), 31 October 1985.

11. Drogoudi, P.D.; Pantelidis, G. Effects of position on canopy and harvest time on fruit physico-chemical and antioxidant properties in different apple cultivars. Sci. Hortic. 2011, 129, 752-760. [CrossRef]

12. Mignard, P.; Beguería, S.; Reig, G.; Forcada, C.F.i.; Moreno, M.A. Genetic origin and climate determine fruit quality and antioxidant traits on apple (Malus $x$ domestica Borkh). Sci. Hortic. 2021, 285, 110142. [CrossRef]

13. Das, I.; Arora, A. Post-harvest processing technology for cashew apple-A review. J. Food Eng. 2017, 194, 87-98. [CrossRef]

14. Mditshwa, A.; Fawole, O.A.; Opara, U.L. Recent developments on dynamic controlled atmosphere storage of apples-A review. Food Packag. Shelf Life 2018, 16, 59-68. [CrossRef]

15. Soliva-Fortuny, R.; Martín-Belloso, O. Fresh-cut fruits: Apples and pears. In Controlled and Modified Atmospheres for Fresh and Fresh-Cut Produce; Gil, M.I., Beaudry, R., Eds.; Elsevier Inc.: London, UK, 2020; pp. 487-494. [CrossRef]

16. Vidović, S.; Tepić, A.; Horecki, J.V.; Šumić, Z.; Gavarić, A.; Vakula, A. Apple. In Valorization of Fruit Processing By-Products; Galanakis, C., Ed.; Elsevier Inc.: London, UK, 2020; pp. 17-42. [CrossRef]

17. Awasthi, M.K.; Ferreira, J.A.; Sirohi, R.; Sarsaiya, S.; Khoshnevisan, B.; Baladi, S.; Sindhu, R.; Binod, P.; Pandey, A.; Juneja, A.; et al. A critical review on the development stage of biorefinery systems towards the management of apple processing-derived waste. Renew. Sustain. Energy Rev. 2021, 143, 110972. [CrossRef]

18. Dhillon, G.S.; Kaur, S.; Brar, S.K. Perspective of apple processing wastes as low-cost substrates for bioproduction of high value products: A review. Renew. Sustain. Energy Rev. 2013, 27, 789-805. [CrossRef]

19. Szczepańska, J.; Pinto, C.A.; Skapska, S.; Saraiva, J.A.; Marszałek, K. Effect of static and multi-pulsed high pressure processing on the rheological properties, microbial and physicochemical quality, and antioxidant potential of apple juice during refrigerated storage. LWT—Food Sci. Technol. 2021, 150, 112038. [CrossRef]

20. Ferrentino, G.; Morozova, K.; Mosibo, O.K.; Ramezani, M.; Scampicchio, M. Biorecovery of antioxidants from apple pomace by supercritical fluid extraction. J. Clean. Prod. 2018, 186, 253-261. [CrossRef]

21. Ito, V.C.; Alberti, A.; Avila, S.; Spoto, M.; Nogueira, A.; Wosiacki, G. Effects of gamma radiation on the phenolic compounds and In Vitro antioxidant activity of apple pomace flour during storage using multivariate statistical techniques. Innov. Food Sci. Emerg. Technol. 2016, 33, 251-259. [CrossRef]

22. Suárez, B.; Álvarez, Á.L.; García, Y.D.; del-Barrio, G.; Lobo, A.P.; Parra, F. Phenolic profiles, antioxidant activity and in vitro antiviral properties of apple pomace. Food Chem. 2010, 120, 339-342. [CrossRef] 
23. Wang, X.; Li, C.; Liang, D.; Zou, Y.; Li, P.; Ma, F. Phenolic compounds and antioxidant activity in red-fleshed apples. J. Funct. Foods 2015, 18, 1086-1094. [CrossRef]

24. Fernández-Jalao, I.; Sánchez-Moreno, C.; De-Ancos, B. Effect of high-pressure processing on flavonoids, hydroxycinnamic acids, dihydrochalcones and antioxidant activity of apple 'Golden Delicious' from different geographical origin. Innov. Food Sci. Emerg. Technol. 2019, 51, 20-31. [CrossRef]

25. Khanizadeh, S.; Tsao, R.; Rekika, D.; Yang, R.; Charles, M.T.; Rupasinghe, H.P.V. Polyphenol composition and total antioxidant capacity of selected apple genotypes for processing. J. Food Compos. Anal. 2008, 21, 396-401. [CrossRef]

26. Kidoń, M.; Grabowska, J. Bioactive compounds, antioxidant activity, and sensory qualities of red-fleshed apples dried by different methods. LWT_Food Sci. Technol. 2021, 136, 110302. [CrossRef]

27. Kim, A.-N.; Lee, K.-Y.; Rahman, M.S.; Kim, H.-J.; Kerr, W.L.; Choi, S.-G. Thermal treatment of apple puree under oxygen-free condition: Effect on phenolic compounds, ascorbic acid, antioxidant activities, color, and enzyme activities. Food Biosci. 2021, 39, 100802. [CrossRef]

28. Łata, B. Apple peel antioxidant status in relation to genotype, storage type and time. Sci. Hortic. 2008, 117, 45-52. [CrossRef]

29. Łysiak, G.P.; Michalska-Ciechanowska, A.; Wojdyło, A. Postharvest changes in phenolic compounds and antioxidant capacity of apples cv. Jonagold growing in different locations in Europe. Food Chem. 2020, 310, 125912. [CrossRef]

30. Pires, T.C.S.P.; Dias, M.I.; Barros, L.; Alves, M.J.; Oliveira, M.B.P.P.; Santos-Buelga, C.; Ferreira, I.C.F.R. Antioxidant and antimicrobial properties of dried Portuguese apple variety (Malus domestica Borkh. cv. Bravo de Esmolfe). Food Chem. 2018, 240, 701-706. [CrossRef]

31. Santarelli, V.; Neri, L.; Sacchetti, G.; Di-Mattia, C.D.; Mastrocola, D.; Pittia, P. Response of organic and conventional apples to freezing and freezing pretreatments: Focus on polyphenols content and antioxidant activity. Food Chem. 2020, 308, 125570. [CrossRef]

32. Stanger, M.C.; Steffens, C.A.; Soethe, C.; Moreira, M.A.; do-Amarante, C.V.T.; Both, V.; Brackmann, A. Phenolic compounds content and antioxidant activity of 'Galaxy' apples stored in dynamic controlled atmosphere and ultralow oxygen conditions. Postharvest Biol. Technol. 2018, 144, 70-76. [CrossRef]

33. Zhao, T.; Sun, L.; Wang, Z.; Nisar, T.; Gong, T.; Li, D.; Niu, P.; Guo, Y. The antioxidant property and $\alpha$-amylase inhibition activity of young apple polyphenols are related with apple varieties. LWT_Food Sci. Technol. 2019, 111, 252-259. [CrossRef]

34. Zheng, H.-Z.; Kim, Y.-I.; Chung, S.-K. A profile of physicochemical and antioxidant changes during fruit growth for the utilisation of unripe apples. Food Chem. 2012, 131, 106-110. [CrossRef]

35. Alvarez, L.V.H.; Zielinski, A.A.F.; Alberti, A.; Nogueira, A. Monitoring of the phenolic compounds and in vitro antioxidant activity of apple beverages according to geographical origin and their type: A chemometric study. LWT-Food Sci. Technol. 2017, 84, 385-393. [CrossRef]

36. Raudone, L.; Raudonis, R.; Liaudanskas, M.; Janulis, V.; Viskelis, P. Phenolic antioxidant profiles in the whole fruit, flesh and peel of apple cultivars grown in Lithuania. Sci. Hortic. 2017, 216, 186-192. [CrossRef]

37. Mishra, K.; Ojha, H.; Chaudhury, N.K. Estimation of antiradical properties of antioxidants using DPPH· assay: A critical review and results. Food Chem. 2012, 130, 1036-1043. [CrossRef]

38. Pyrzynska, K.; Pękal, A. Application of free radical diphenylpicrylhydrazyl (DPPH) to estimate the antioxidant capacity of food samples. Anal. Methods 2013, 5, 4288-4295. [CrossRef]

39. Krishnaiah, D.; Sarbatly, R.; Nithyanandam, R. A review of the antioxidant potential of medicinal plant species. Food Bioprod. Process. 2011, 89, 217-233. [CrossRef]

40. López-Alarcóna, C.; Denicola, A. Evaluating the antioxidant capacity of natural products: A review on chemical and cellular-based assays. Anal. Chim. Acta 2013, 763, 1-10. [CrossRef]

41. Vieira, F.G.K.; Borges, G.D.S.C.; Copetti, C.; Amboni, R.D.D.M.C.; Denardi, F.; Fett, R. Physico-chemical and antioxidant properties of six apple cultivars (Malus domestica Borkh) grown in southern Brazil. Sci. Hortic. 2009, 122, 421-425. [CrossRef]

42. Vieira, F.G.K.; Borges, G.D.S.C.; Copetti, C.; Di-Pietro, P.F.; da-Costa-Nunes, E.; Fett, R. Phenolic compounds and antioxidant activity of the apple flesh and peel of eleven cultivars grown in Brazil. Sci. Hortic. 2011, 128, 261-266. [CrossRef]

43. Fernández-González, A.; Montejo-Bernardo, J.M.; Rodríguez-Prieto, H.; Castaño-Monllor, C.; Badía-Laíño, R.; Díaz-García, M.E. Easy-to-use analytical approach based on ATR-FTIR and chemometrics to identify apple varieties under Protected Designation of Origin (PDO). Comput. Electron. Agric. 2014, 108, 166-172. [CrossRef]

44. Francini, A.; Romeo, S.; Cifelli, M.; Gori, D.; Domenici, V.; Sebastiani, L. ${ }^{1} \mathrm{H}$ NMR and PCA-based analysis revealed variety dependent changes in phenolic contents of apple fruit after drying. Food Chem. 2017, 221, 1206-1213. [CrossRef] [PubMed]

45. Reid, L.M.; Woodcock, T.; O’Donnell, C.P.; Kelly, J.D.; Downey, G. Differentiation of apple juice samples on the basis of heat treatment and variety using chemometric analysis of MIR and NIR data. Food Res. Int. 2005, 38, 1109-1115. [CrossRef]

46. Włodarska, K.; Piasecki, P.; Lobo-Prieto, A.; Pawlak-Lemańska, K.; Górecki, T.; Sikorska, E. Rapid screening of apple juice quality using ultraviolet, visible, and near infrared spectroscopy and chemometrics: A comparative study. Microchem. J. 2021, 164, 106051. [CrossRef]

47. Zielinski, A.A.F.; Alberti, A.; Braga, C.M.; da-Silva, K.M.; Canteri, M.H.G.; Mafra, L.I.; Granato, D.; Nogueira, A.; Wosiacki, G. Effect of mash maceration and ripening stage of apples on phenolic compounds and antioxidant power of cloudy juices: A study using chemometrics. LWT-Food Sci. Technol. 2014, 57, 223-229. [CrossRef] 
48. Denver, S.; Jensen, J.D. Consumer preferences for organically and locally produced apples. Food Qual. Prefer. 2014, 31, 129-134. [CrossRef]

49. Keyes, S.; Tyedmers, P.; Beazley, K. Evaluating the environmental impacts of conventional and organic apple production in Nova Scotia, Canada, through life cycle assessment. J. Clean. Prod. 2015, 104, 40-51. [CrossRef]

50. Longo, S.; Mistretta, M.; Guarino, F.; Cellura, M. Life Cycle Assessment of organic and conventional apple supply chains in the North of Italy. J. Clean. Prod. 2017, 140, 654-663. [CrossRef]

51. Meyerding, S.G.H.; Merz, N. Consumer preferences for organic labels in Germany using the example of apples-Combining choice-based conjoint analysis and eye-tracking measurements. J. Clean. Prod. 2018, 181, 772-783. [CrossRef]

52. Moscetti, R.; Raponi, F.; Ferri, S.; Colantoni, A.; Monarca, D.; Massantini, R. Real-time monitoring of organic apple (var. Gala) during hot-air drying using near-infrared spectroscopy. J. Food Eng. 2018, 222, 139-150. [CrossRef]

53. Raffo, A.; D'Aloise, A.; Lardschneider, E.; Paoletti, F.; Marini, F.; Bucci, R.; Kelderer, M. Effect of soil nutrition on aroma compound formation in organically grown apples (cv. Golden Delicious). In Flavour Science; Ferreira, V., Lopez, R., Eds.; Elsevier Inc.: Amsterdam, The Netherlands, 2014; pp. 173-176.

54. Raffo, A.; Baiamonte, I.; Bucci, R.; D'Aloise, A.; Kelderer, M.; Matteazzi, A.; Moneta, E.; Nardo, N.; Paoletti, F.; Peparaio, M. Effects of different organic and conventional fertilisers on flavour related quality attributes of cv. Golden Delicious apples. LWT-Food Sci. Technol. 2014, 59, 964-972. [CrossRef]

55. Róth, E.; Berna, A.; Beullens, K.; Yarramraju, S.; Lammertyn, J.; Schenk, A.; Nicolaï, B. Postharvest quality of integrated and organically produced apple fruit. Postharvest Biol. Technol. 2007, 45, 11-19. [CrossRef]

56. Song, W.; Jiang, N.; Wang, H.; Guo, G. Evaluation of machine learning methods for organic apple authentication based on diffraction grating and image processing. J. Food Compos. Anal. 2020, 88, 103437. [CrossRef]

57. Roussos, P.A.; Gasparatos, D. Apple tree growth and overall fruit quality under organic and conventional orchard management. Sci. Hortic. 2009, 123, 247-252. [CrossRef]

58. Heinmaa, L.; Moor, U.; Põldma, P.; Raudsepp, P.; Kidmose, U.; Lo-Scalzo, R. Content of health-beneficial compounds and sensory properties of organic apple juice as affected by processing technology. LWT-Food Sci. Technol. 2017, 85, 372-379. [CrossRef]

59. Bahukhandi, A.; Dhyani, P.; Bhatt, I.D.; Rawal, R.S. Variation in polyphenolics and antioxidant activity of traditional apple cultivars from West Himalaya, Uttarakhand. Hortic. Plant J. 2018, 4, 151-157. [CrossRef]

60. Shen, Y.; Zhu, D.; Xi, P.; Cai, T.; Cao, X.; Liu, H.; Li, J. Effects of temperature-controlled ultrasound treatment on sensory properties, physical characteristics and antioxidant activity of cloudy apple juice. LWT_Food Sci. Technol. 2021, 142, 111030. [CrossRef]

61. Gligor-(Pane), D.; Hădărugă, D.I.; Hădărugă, N.G. Quality and authenticity of the forest fruits through antioxidant compounds-A review on chemometric tools. J. Agroaliment. Process. Technol. 2020, 26, 251-257.

62. Hegheş, A.; Hădărugă, N.G.; Fuliaş, A.-V.; Bandur, G.N.; Hădărugă, D.I.; Dehelean, C.-A. Capsicum annuum extracts/ $\beta$ cyclodextrin complexes. Thermal analyses-Karl Fischer water titration correlations and antioxidant activity. J. Therm. Anal. Calorim. 2015, 120, 603-615. [CrossRef]

63. Ivanovici, M.; Sicoe, G.; Hădărugă, D.I. Kinetics and antiradical activity of natural and synthetic phenolic compounds by DPPH method: A comparative study. J. Agroaliment. Process. Technol. 2018, 24, 97-103.

64. Oprinescu, C.; Hădărugă, D.I.; Hădărugă, N.G. A critical review on the antioxidant analysis and composition of Vitis species. J. Agroaliment. Process. Technol. 2020, 26, 429-440.

65. Costescu, C.I.; Rus, D.; Hădărugă, N.G.; Pogor, V.; Badea, M.; Mateican, E.; Szakal, R.; Olaru, P.; Hădărugă, D.I. Solvent influence on the antioxidant activity of pomegranate extracts. J. Agroaliment. Process. Technol. 2015, 21, 21-27.

66. Sicoe, G.; Oprinescu, C.I.; Golea, G.M.; Riviş, A.; Hădărugă, N.G. Kinetics on the DPPH. reaction with hydroalcoholic extracts from various pomegranate parts. J. Agroaliment. Process. Technol. 2017, 23, 271-280.

67. Hădărugă, D.I.; Pantea, C.; Hădărugă, N.G. Antioxidant activity and kinetics on kiwi fruit (Actinidia deliciosa) ethanolic extracts by 2,2-diphenyl-1-picrylhydrazyl (DPPH.) method. J. Agroaliment. Process. Technol. 2016, 22, 207-211.

68. Iordănescu, O.A.; Băla, M.; Gligor-(Pane), D.; Zippenfening, S.E.; Cugerean, M.I.; Petroman, M.I.; Hădărugă, D.I.; Hădărugă, N.G.; Riviş, M. A DPPH·kinetic approach on the antioxidant activity of various parts and ripening levels of papaya (Carica papaya L.) ethanolic extracts. Plants 2021, 10, 1679. [CrossRef]

69. Bondet, V.; Brand-Williams, W.; Berset, C. Kinetics and mechanisms of antioxidant activity using the DPPH free radical method. Lebensmittel-Wissenschaft und -Technologie 1997, 30, 609-615. [CrossRef]

70. Brand-Williams, W.; Cuvelier, M.E.; Berset, C. Use of a free radical method to evaluate antioxidant activity. LebensmittelWissenschaft und -Technologie 1995, 28, 25-30. [CrossRef]

71. Dawidowicz, A.L.; Wianowska, D.; Olszowy, M. On practical problems in estimation of antioxidant activity of compounds by DPPH method (Problems in estimation of antioxidant activity). Food Chem. 2012, 131, 1037-1043. [CrossRef]

72. Nićiforović, N.; Polak, T.; Makuc, D.; Ulrih, N.P.; Abramovič, H. A kinetic approach in the evaluation of radical-scavenging efficiency of sinapic acid and its derivatives. Molecules 2017, 22, 375. [CrossRef] [PubMed]

73. Schaich, K.M.; Tian, X.; Xie, J. Hurdles and pitfalls in measuring antioxidant efficacy: A critical evaluation of ABTS, DPPH, and ORAC assays. J. Funct. Foods 2015, 14, 111-125. [CrossRef]

74. Cevallos-Casals, B.A.; Cisneros-Zevallos, L. Stoichiometric and kinetic studies of phenolic antioxidants from andean purple corn and red-fleshed sweetpotato. J. Agric. Food Chem. 2003, 51, 3313-3319. [CrossRef] [PubMed] 
75. Fadda, A.; Serra, M.; Molinu, M.G.; Azara, E.; Barberis, A.; Sanna, D. Reaction time and DPPH concentration influence antioxidant activity and kinetic parameters of bioactive molecules and plant extracts in the reaction with the DPPH radical. J. Food Compos. Anal. 2014, 35, 112-119. [CrossRef]

76. Savatović, S.M.; Ćetković, G.S.; Čanadanović-brunet, J.M.; Djilas, S.M. Kinetic behaviour of the DPPH radical-scavenging activity of tomato waste extracts. J. Serb. Chem. Soc. 2012, 77, 1381-1389. [CrossRef]

77. López-Nicolá, J.M.; Núñez-Delicado, E.; Sánchez-Ferrer, Á.; García-Carmona, F. Kinetic model of apple juice enzymatic browning in the presence of cyclodextrins: The use of maltosyl- $\beta$-cyclodextrin as secondary antioxidant. Food Chem. 2007, 101, 1164-1171. [CrossRef] 